ANUARIo DE Estudios MediEvales (AEM)

36/2, julio-diciembre de 2006

pp. 713-750

ISSN 0066-5061

\title{
BANDOS Y BANDOSITATS \\ EN LA GOBERNACIÓN DE ORIHUELA EN LA BAJA EDAD MEDIA
}

\author{
JoSÉ HiNOJOSA MONTALVO \\ Universidad de Alicante
}

Resumen: Durante los siglos bajo-medievales las guerras urbanas alcanzaron gran difusión por todo Occidente. El reino de Valencia no fue una excepción ni tampoco las comarcas meridionales del mismo, a las que vemos inmersas en estos siglos en luchas de banderías. Los linajes nobiliarios y ciudadanos de Orihuela, Alicante, Cocentaina, etc. se enfrentaron a mano armada por el control de los oficios municipales, por mantener el poder y el prestigio en el seno de la sociedad local, por defender el honor o por adaptarse a las nuevas realidades económicas del momento.

Palabras clave: Ciudades; Tensiones sociales; Banderías; Orihuela; Alicante; Cocentaina.

\begin{abstract}
During low-medieval centuries, urban wars achieved a great diffusion throughout all Occident. The Kingdom of Valencia was no exception neither the meridian regions of the same, who we see immersed during these centuries in bandit fights. The noble and citizen linage of Orihuela, Alicante, Cocentaina, etc. fought armed hand for the control of the municipal jobs, to defend ones honour or to adapt to the new economical realities of the moment.
\end{abstract}

Keywords: Cities; Social conflicts; Parties; Orihuela; Alicante; Cocentaina.

\section{SUMARIO}

1. Fuentes y bibliografía.- 2. Causas de los bandos.- 3. Bandos en Orihuela.- 4. Bandos en otras localidades.

Dentro de la dinámica económico-social de las ciudades bajomedievales y afectando a todos los grupos sociales nos encontramos con las violencias urbanas, un evento que afectó a todas las ciudades mediterráneas y que en Valencia alcanzó particular virulencia. Se trata de una violencia constituida por las bandositats que protagonizaron los bàndols de los nobles y que se manifestó de forma cotidiana por las calles de nuestras ciudades y villas, entre ellas las del mediodía del reino valenciano, objeto del presente estudio. 


\section{FUENTES Y BIBLIOGRAFÍA}

Quienes se han ocupado de estas luchas de banderías han recurrido sobre todo a las Actas capitulares o Manuals de Consells de una localidad, libros en los que constan los acuerdos tomados por la municipalidad y en los que podemos seguir relativamente bien tales luchas, siempre que supusieran una grave alteración ciudadana o la violencia alcanzara límites intolerables. Digo esto porque dichas actas no recogen todas las noticias referentes a estos enfrentamientos, y son muy pocas las localidades del sur del reino que conservan documentación de este tipo (Alcoy, Elche, Orihuela), que además siempre comienza a partir de los años ochenta del siglo XIV, finalizada la guerra de los "dos Pedros". El caso de Orihuela lo refleja muy bien. Si estudiamos las actas los años setenta y ochenta del siglo XV, por ejemplo, apenas encontramos alguna noticia sobre banderías, en tanto que la documentación real nos ofrece numerosas noticias de tales choques. Por eso el complemento indispensable de esta fuente son los registros de la Real Cancillería, tanto del Archivo de la Corona de Aragón como del Archivo del Reino de Valencia, ya que la Corona era la mediadora entre los bandos enfrentados. También los libros de la Cort del Justicia, allí donde se conservan, son de gran utilidad para el estudiosos del tema, al contener noticias sobre las paus e treves firmadas entre dichos bandos.

La bibliografía sobre los bandos es ya antigua, pues todos los cronistas se hicieron eco de tales luchas, si bien es a partir del estudio de S. Carreres en 1930 cuando disponemos de los primeros trabajos científicos en torno al tema ${ }^{1}$, que no tuvieron mucha continuidad hasta fecha reciente, en que se ha reactivado su estudio al calor del interés suscitado por los conflictos sociales bajo-medievales y el desarrollo de la institución municipal. Así en las décadas finales de la centuria pasada aparecieron los estudios de R. Ferrero Micó sobre la paz y tregua, ampliado luego a las banderías durante la época foral $^{2}$, en tanto que R. Narbona ha convertido el análisis de las luchas ciudadanas y el poder político en uno de sus ejes de investigación, renovando el panorama en torno al municipio valenciano ${ }^{3}$. Por su parte E. Salvador ha reflexionado sobre los bandos y las fórmulas de solidaridad y la instrumentalización que la Corona hizo de tales luchas, aunque focalizadas, sobre todo, en

S. CARRERES ZACARÉs, Notes per a la història dels bandos de Valencia, Valencia, 1926.

${ }^{2}$ R. FERrero Micó, "Pau e treua" en Valencia, "Estudios a Juan Peset Aleixandre", Valencia, Universidad, II", 1982 , pp. 1-15; EADEM, Bandosidades nobiliarias en Valencia durante la época foral, "Saitabi", XXXV (1985), pp. 95-110.

${ }^{3}$ R. NARBONA VIZCAÍNO, Gobierno político y luchas sociales: patricios y malhechores, "Saitabi", XXXIX (1989), pp. 81-98; IDEM, Gobierno politico y luchas sociales: patricios y malhechores. Siglos XIV y XV, en Lluís de Santàngel i el seu temps, Valencia, 1992, pp. 229-240; IDEM, Valencia, municipio medieval. Poder politico y luchas ciudadanas (1239-1418), Valencia, Ayuntamiento, 1995. 
la Edad Moderna ${ }^{4}$. Pero todos ellos han centrado su investigación en la ciudad de Valencia, donde existen más fuentes y el fenómeno de las banderías alcanzó mayor complejidad y espectacularidad.

En fecha reciente C. López Rodríguez ha publicado un excelente estudio sobre la nobleza y el poder político en el reino de Valencia entre los años 1416 y 1446, en el que dedica varios apartados a los bandos nobiliarios y el gobierno del reino entre 1416 y 1429, así como a la actitud de la nobleza ante las elecciones municipales, o los bandos durante las Cortes de Valencia de 1437-38, de gran interés para ver cómo fue evolucionando la nobleza ante los cambios políticos, sociales y económicos que se estaban produciendo, así como las tensiones que ello produjo en el seno del grupo oligárquico. Sin embargo, no encontramos alusiones a las comarcas meridionales del reino ${ }^{5}$.

En lo referente a las tierras meridionales del reino hay que señalar que la importancia de los bandos en Orihuela no pasó desapercibida a los historiadores locales, y ya el rector de Catral y cronista mosén Pedro Bellot en sus Anales de Orihuela, dedicó el capítulo X a este complejo asunto, que atormentó la vida de los oriolanos durante varios siglos. Lo titulaba "De los bandos que han tenido en tiempos pasados los de Orihuela. Rocafull y Mirón", datando los más antiguos en 1383 y abarcando hasta el reinado de Juan II, algo lógico, si tenemos en cuenta que Bellot manejaba básicamente las Actas Capitulares, los acuerdos del Consell, para elaborar su historia, desconociendo fuentes más antiguas o de otra procedencia. Pero Bellot carecía de espíritu crítico y capacidad de análisis y se limitó a exponer los sucesos, a menudo de forma confusa, sin explicar las causas, ya que lo que le interesaba era la paz entre estos bandos y el protagonismo en el conflicto de los grupos privilegiados de la sociedad ${ }^{6}$. Con todo, Bellot nos aporta una enorme cantidad de datos, que autores posteriores se han limitado a copiar, sin apenas modificaciones ni consultar las fuentes originales en la mayoría de los casos.

Con una metodología y unos planteamientos adecuados a las corrientes historiográficas actuales hay que citar los trabajos $\mathrm{M}^{\mathrm{a}} \mathrm{T}$. Ferrer i Mallol en torno a los enfrentamientos entre la pequeña nobleza urbana y los homes de vila en Orihuela por el poder municipal ${ }^{\dagger}, \mathrm{y}$ los de J.A. Barrio Barrio sobre el

\footnotetext{
${ }^{4}$ E. SALVADOR ESTEBAN, Bandos y fórmulas de solidaridad. La instrumentalización de las rivalidades de los poderosos por la Corona "XVII Congrés d' Historia de la Corona d'Aragó", Barcelona, Universitat, 2002, T. I, pp. 19-34.

${ }^{5}$ C. LóPEz RodRíGUEZ, Nobleza y poder político. El reino de Valencia (1415-1446), Valencia, Universitat, 2005.

${ }^{6}$ Mossén Pedro Bellot, Anales de Orihuela (siglos XIV-XVI). Estudio, edición y notas del Dr. D. Juan TORRES FONTES, Oriola Publicaciones del Casino Orcelitano-Patronato Artístico de Orihuela, 1954-56, 2 vols. 505+412 pp.

${ }^{7} \mathrm{M}^{\mathrm{a}} \mathrm{T}$. FERRER I MALLOL, Discòrdies entre la petita noblesa urbana i els homes de vila a les terres meridionals valencianes en el primer terç del segle XIV, "Anuario de Estudios medievales", 29, (1999), pp. 301-314.
} 
municipio oriolano ${ }^{8}$, así como el de A.R. Bas Albertos, quien realizó su Memoria de Licenciatura en torno al tema "Conflictividad y poder. Violencias urbanas en las tierras alicantinas a finales de la Edad Media", donde con una excelente metodología desmenuza e interpreta las luchas producidas por los nobles en Orihuela, partiendo de las noticias facilitadas por el cronista P. Bellot ${ }^{9}$.

\section{CAUSAS DE LOS BANDOS}

Los siglos bajo-medievales se caracterizan por una afirmación del poder real y por la búsqueda por parte de la nobleza y de los grupos ciudadanos de una consolidación de sus privilegios estamentales. Las banderías urbanas forman parte de las luchas políticas y económicas de los distintos grupos sociales, con preferencia de los privilegiados, de las elites locales que tratan de lograr el control político del municipio, con todo lo que ello implicaba. Estamos también ante una reacción de dichos grupos ante los profundos cambios que se estaban produciendo en la economía en la baja Edad Media $^{10}$. Los estudios de R. Narbona para la ciudad de Valencia han puesto de manifiesto las numerosas estrategias desplegadas por el patriciado urbano para el control de las instituciones municipales y sus áreas de poder. El control de la elección de los jurats y el Consell estuvo siempre en manos de las familias patricias, cuyas estrategias para hacerse con dicho control generaron un alto índice de conflictividad social en las calles, estando demostrada "la vinculación entre los partidos patricios y las sangrientas luchas callejeras" ${ }^{11}$. Las familias utilizaban las solidaridades del linaje como una estrategia social y política para construir su poder en la ciudad medieval ${ }^{12}$.

Hubo también otros factores que propiciaron este enfrentamiento de bandos como fue la venganza para reparar el honor y el combate de los caballeros, ya que tanto el primero como su actitud guerrera son aspectos

${ }^{8}$ J.A. BARRIO BARRIO, El ejercicio del poder en un municipio medieval: Orihuela 13081479, Ailicante, Universidad, 1993; IDEM, La intervención real en la ciudad de Orihuela a través de la implantación de la insaculación en 1445 , "XV Congreso de Historia de la Corona de Aragón", Zaragoza, 1996 tomo 1 pp.25-34; IDEM, Gobierno municipal en Orihuela durante el reinado de Alfonso V: 1416-1458, Alicante, 1996; IDEM, La articulación de una oligarquía fronteriza en el mediodía valenciano. El patriciado de Orihuela. Siglos XIV-XV, "Revista d'Història Medieval", 9, (1998), pp, 105-126; IDEM, Las élites políticas urbanas en la Gobernación de Orihuela. Los sistemas de creación acceso y reproducción del grupo dirigente en un territorio fronterizo, Anuario de Estudios Medievales, 32/2 (2002), pp. 777-808, pp. 777 808.

${ }^{9}$ A.R. BAS ALBERTOS, “Conflictividad y poder. Violencias urbanas en las tierras alicantinas a finales de la Edad Media", Memoria de Licenciatura dirigida por el Dr. J. V. Cabezuelo Pliego. Alicante, Facultad de filosofía y letras, 1999.

${ }^{10}$ R. NARBONA VizCAÍnO, Valencia, municipio medieval. Poder político y luchas ciudadanas (1239-1418), Valencia, Ayuntamiento, 1995, p. 148.

${ }^{11}$ R. NARBONA VIZCAÍNO, Gobierno político y luchas sociales: patricios y malhechores. Siglos $X I V$ y XV, "Lluís de Santàngel i el seu temps", Valencia, 1992, pp. 229-240.

${ }^{12} \mathrm{G}$. LANSING, The Florentine Magnates Lineage and faction in Medieval commune, Princeton, Princeton University Press, 1991, p. XII. 
fundamentales en la vida de los nobles. El mantenimiento del prestigio de la familia llevaba a la agresión, con la que se trataba de hacer valer el honor familiar, el prestigio de la casa y su preeminencia en el seno de la sociedad local o del reino. El control del gobierno municipal era el medio para seguir manteniendo esta posición, algo difícil para la alta nobleza, dado que era el patriciado urbano el que monopolizaba los oficios municipales, si bien desde 1329 en Valencia la nobleza participó también en el gobierno municipal, si bien de forma minoritaria. Aunque de forma directa los nobles de primera categoría no intervenían en el poder municipal, en realidad sí que lo hacían de forma indirecta a través de sus clientelas y alianzas. Y es que, como señala R. Narbona, "en última instancia, no hay que olvidar que el desempeñar "indirectamente" los oficios municipales es un medio directo de multiplicar sus rentas e ingresos, de hacer valer sus intereses y materializar su preeminencia social" 13 .

La sociedad medieval, más preocupada por el rango social que por el dinero, era una sociedad violenta, en la que a la agresión se respondía con violencia, generando una situación conflictiva, que puede desembocar en la muerte. Por otra parte, pocas veces los linajes nobiliarios se encontraban frente a ellos una autoridad capaz de imponerse, pues a menudo las autoridades municipales o reales estaban implicadas en las propias banderías o, como sucedía en la gobernación de Orihuela, no era raro que el gobernador estuviera ausente de la localidad. Esta debilidad del poder real propició, sin duda, la creación y continuidad de las banderías

A fines del XIV entramos en una sociedad en profundos cambios económicos, sociales y políticos, que se tradujeron en un incremento de la violencia nobiliaria, en particular durante los reinados de Juan I, Martín el Humano y el Interregno que siguió a su muerte. La ausencia de poder desencadenó auténticas batallas campales, sobre todo en la ciudad de Valencia entre los Centelles y los Vilaraguts, pero con repercusiones en el resto del reino. Sin embargo, por estas fechas el reino de Valencia había entrado ya en una dinámica precapitalista gracias al desarrollo de una economía mercantil, que propició el ascenso de unas clases urbanas cada vez con más recursos monetarios, en tanto que la nobleza, que seguía manteniendo un nivel de vida acorde a su posición social, veía como sus rentas no crecían al mismo nivel y con frecuencia era víctima de sus acreedores. Estas dificultades de la nobleza la llevaron en último término a utilizar la violencia contra sus rivales, en ausencia de otras empresas militares que permitieran canalizar la combatividad del grupo nobiliario.

También en el trasfondo de estas banderías había viejas disputas entre los nobles por la fuerza de trabajo de sus vasallos, por atraerse vasallos hacia sus señoríos a costa de otros, lo que produjo una fuerte competencia entre ellos que en ocasiones llegó al enfrentamiento, amenazando la paz pública.

\footnotetext{
${ }^{13}$ R. NARBONA VizCAínO, Violencias feudales en la ciudad de Valencia, "Revista d'Història Medieval", 1, Valencia, 1990, pp. 59-86. En concreto en la p. 75. 
Las luchas entre los Roiç de Corella y los Maça de Liçana en el valle del Vinalopó durante el siglo XV son un buen ejemplo de tales rivalidades. En los orígenes de los bandos tampoco faltaron las disputas nobiliarias por la herencia, el patrimonio y las jurisdicciones señoriales,

¿Qué entendemos por bando? Según J. Valdeón el bando es una agrupación de linajes que proceden del mismo tronco o entre los que se anudan lazos de parentescos ${ }^{14}$. La sociedad urbana medieval se estructuró en torno a clientelas y fidelidades generando redes humanas que reconocen una autoridad suprema y otras secundarias, bajo la autoridad de uno o varios jefes. El cabeza del bando establecía relaciones con sus iguales sociales generando alianzas de tipo horizontal, como eran las llamadas cartas de amistad, reforzadas con cláusulas de tipo defensivo frente a terceros, en sus personas $\mathrm{y}$ bienes.

En la concepción que se tenía y que tenemos del bando subyace una característica clave: la idea de familia, de pertenecer todos a un mismo tronco, a la que se añaden las de vecindad y las alianzas ocasionales. Los jefes de los bandos, los parientes mayores del clan, defendían con las armas su apellido, como era el caso en Orihuela de los Rocafull, Rocamora, Miró, Masquefas, etc, residiendo en viviendas fortificadas y eran los que ponía al linaje en pie de guerra. Por su parte los parientes menores (donceles, caballeros, escuderos, hidalgos), els valedors de los documentos, ayudaban y protegían a sus señores, pero contaban con un rango y una condición inferior, a veces rayando la pobreza, por lo que necesitaban para sobrevivir de la hospitalidad de los grandes linajes.

Estas banderías no son sino guerras privadas nobiliarias, que se desarrollan siempre en un marco local y en la que participaban las familias cabezas del linaje con sus parientes, aliados y amigos, que asistían al jefe en su venganza.

A la agresión se respondía con la venganza para reparar el honor y para atemorizar al contrario, presentándose la venganza no como algo individual sino colectivo, que agrupa a todos los miembros de una familia, sus parientes y amigos. Lo vemos, por ejemplo, en Cocentaina en la violencia que estalló en 1396 y que tuvo como origen el asesinato por algunos vecinos de la villa de otro vecino, provocando que todos los habitantes, reclamando la venganza de sangre, se alzaran en armas contra los culpables y sus valedores. Ante tales desórdenes el 2 de enero de 1397 la reina Violante ordenaba al justicia local que capturara a los culpables y se los remitiera para darles el castigo correspondiente ${ }^{15}$.

El panorama que ofrecen las comarcas alicantinas en esta lucha de bandos no se diferencia de la capital del reino y podemos afirmar que la formación de las banderías tenía como principal objetivo el control de los

\footnotetext{
${ }^{14}$ J. VALDEÓN BARUQUE, Los conflictos sociales en el reino de Castilla en los siglos XIV y $X V$, Madrid, Siglo XXI, 1975 , p.p. 63-65.

${ }^{15}$ ACA, C, reg. 2047, f. 64 v. 2-1-1397, Barcelona. 
oficios municipales por parte de los nobles, del Consell local, ya que ello les permitiría multiplicar sus ingresos, hacer valer sus intereses, sobre todo en materia fiscal, a la vez que resaltar su preeminencia social. En definitiva, poder y prestigio, a costa, claro está, del bando contrario, al que había que tener neutralizado mediante el uso de la violencia. Naturalmente, las familias que ansiaban el poder, utilizaron también los instrumentos legales de acceso a los organismos de gobierno municipal para obtener un mejor control del Consell, visible en Orihuela en el paso de la cooptación indirecta del siglo $\mathrm{XIV}$, a la insaculación en el siglo XV, que permitía una mayor capacidad de intervención de la Corona a través de los oficiales reales. Se mantuvo inalterable, sin embargo, la ocupación anual de los oficios entre los caballeros y los ciudadanos.

El tema, como ya señalé, ha sido bien estudiado por $\mathrm{M}^{\mathrm{a}} \mathrm{T}$. Ferrer $\mathrm{i}$ Mallol para el primer tercio del siglo XIV en las comarcas meridionales del reino de Valencia, las que fueron anexionadas por Jaime II entre 1296 y 1305, un territorio donde, salvo el señorío de Elche, las villas más importantes, Orihuela y Alicante formaron parte del realengo. Estamos en una zona de frontera, la de Castilla y la de Granada, donde la pequeña nobleza, entre urbana y rural, había recibido lotes de tierra en los Repartimientos ${ }^{16}$ que le había permitido constituir pequeños señoríos en el alfoz concejil, pero también donde la amenaza armada (la guerra, las correrías nazaríes) les obligaba a mantener caballo y armas, condición esencial para seguir disfrutando de sus privilegios estamentales.

El paso de la soberanía castellana a la aragonesa provocó tensiones en Orihuela entre este grupo de los caballeros y hombres de paraje, de un lado, y los prohombres locales, los "burgueses", centrados, sobre todo, en el tema de las contribuciones y los gastos municipales, a los que los primeros se mostraban reacios a participar. Por lo general se prefirió la vía pacífica de la reclamación judicial o de las embajadas a la corte en defensa de los intereses propios y no se puede hablar de la formación de bandos en el sentido purista del término. Al menos esto es lo que se desprende de la lectura de la documentación. Lo que no excluye algún episodio violento, como es el que tuvo lugar a comienzos del siglo XIV en Elche. El 15 de mayo de 1301 Bernat de Sarrià notificaba a Jaime II el proceso seguido por él en Elche para restablecer la paz turbada por el pleito habido entre los caballeros y hombres de armas, de un lado, y el Consell ilicitano, del otro, a causa de los fueros y franquicias que los primeros recibieron de don Juan Manuel, liberándolos de ciertos servicios comunitarios, como el de vigilancia, arrobdas, etc, que se negaban a cumplir. Este tira y afloja entre los grupos privilegiados y las autoridades municipales por la defensa de sus respectivos privilegios y competencias fue habitual en todos los municipios de la época, reflejando en este caso los viejos privilegios de la clase feudal castellana que ahora se

\footnotetext{
${ }^{16}$ J. TORRES FonTES, Repartimiento de Orihuela, Murcia, Academia Alfonso X el SabioPatronato "Angel García Rogel", 1988.
} 
insertaba en un nuevo contexto municipal, como era el de la Corona de Aragón.

Si en las dos primeras décadas del siglo XIV la vía pacífica fue la que predominó en la defensa de sus privilegios, a partir de 1325 y 1326 en Orihuela las disensiones entre nobleza y ciudadanos se centraron en las pretensiones de la primera por acceder a los cargos municipales y generaron un mayor clima de violencia. Unas tensiones acordes a las que sucedían en la capital del reino, ya que hay que tener presente que los Furs de València excluían en Orihuela la participación de los caballeros y los hombres de paraje del régimen municipal, en tanto que en Elche y Alicante podían participar todos los estamentos sociales.

Otro motivo por el que se generaban violentos conflictos era la actuación de algunos oficiales reales que provocaba la oposición de los ciudadanos, apoyados por enemigos de aquéllos. Vemos como en la carta enviada el 20 de mayo de 1416 por Alfonso $\mathrm{V}$ al gobernador, justicia y oficiales reales en Orihuela, se alude a la presentación por Joan Masquefa, doncel, de una carta de Fernando I, dada en Montblanch el 5 de diciembre de 1414, en la que el predecesor en el trono de Aragón se dirige a dichas autoridades a propósito de la embajada enviada por las autoridades oriolanas a Morella, donde estaba entonces Fernando I. Los mensajeros fueron mosén Jaume Terres y Bertomeu Montsi de Castantsa, quienes le expusieron los bandos que había en la villa por causa de la citación de dichos oficiales y por una cuestión de embargos entre Orihuela y Caravaca. El objetivo de los mensajeros era cobrar lo que se les adeudaba por su trabajo, pero lo que a nosotros nos interesa es destacar como causa de tales enfrentamientos el comportamiento de los oficiales reales. En efecto procuradores, gobernadores o sus lugartenientes, a menudo con su actuación, de hecho o por omisión, irritaban a las autoridades locales y a los vecinos de Orihuela, Elche y Alicante. Unas veces eran las transgresiones forales o el incumplimiento de los mandatos del monarca o de sus obligaciones como funcionarios, como era la de residencia, o bien la implicación en la lucha de los bandos a favor de uno u otro, generando un fuerte clima de crispación, que obligaba a intervenir a la Corona. Y no era raro que tales desavenencias terminaran con la destitución del funcionario, por muy elevado que fuera su rango. Es el caso de Nicolau de Pròxita, gobernador general de Orihuela, consejero y mayordomo del rey, que fue destituido por Pedro IV el 5 de julio de 1380 en base a las quejas y agravios presentados por los habitantes de Orihuela al monarca, que habían provocado un fuerte descontento entre los habitantes de la gobernación. La situación fronteriza de la misma hacía que el monarca resolviera siempre tales quejas con prontitud y a favor de sus súbditos, ya que la paz del territorio era necesaria frente a castellanos y granadinos.

La venganza para reparar el honor que se consideraba lesionado era otra de las causas de los bandos, y a menudo era un motivo aparentemente banal el que desencadenaba toda una ola de violencia entre bandos, como sucedió en 1440 en Orihuela. Así se desprende de la orden dada el 5 de diciembre por la reina María, esposa de Alfonso V y lugarteniente general, 
a los oficiales reales en la ciudad para que no permitiera que los hermanos Pere, Domingo y Ferran Morote fueran molestados por nadie, debido a las violencias desatadas con los parientes y amigos de los Molins, por causa de la muerte de Francesc de Molins, quien había fallecido por las heridas recibidas en una pelea con los Morote en la huerta de Orihuela. El motivo no había sido otro que una liebre por la que ambas partes disputaban ${ }^{17}$.

Estas peleas eran una de las causas más frecuentes de la formación de bandos locales, aunque los objetivos perseguidos por las partes nada tienen que ver con los de las banderías tradicionales y de larga duración, que no era otro sino conseguir el máximo poder local. Aquí de lo que se trata es de vengar la afrenta sufrida por un miembro de una familia, lo que implicaba al resto de parientes y amigos. Un ejemplo lo tenemos en Alcoy, cuando Peret Botella, un niño que en 1474 tenía unos siete años, mató de forma accidental a otro niño de similar edad, llamado Genís Valls, hijo de Bernat Valls. El suceso fue enjuiciado y se dio sentencia por don Roger Ladró, vizconde de Chelva, y micer Jaume Garcia d'Aguilar, doctor en leyes, árbitros elegidos por las partes, según la cual el agresor, Peret Botella, debía salir por un tiempo de la villa y su término per major tranquilitat e passifficació de la dita vila, siendo aceptada, en principio, por las partes. Sin embargo el padre de Peret y su hijo trataban de impugnar la sentencia y de que su hijo menor entrara en Alcoy, lo que Juan II consideraba escandaloso, dado que el padre del difunto, Barnat Valls, era el cabeza de una familia local destacada (és molt aparentat en la dita vila) y viendo a su hijo muerto hacía poco, él y sus parientes acudirían a la venganza. Había que evitar que ésta se pusiera en marcha, por lo que los jurados alcoyanos pidieron al monarca que interviniera para que se respetara la sentencia, lo que hizo el 27 de octubre de ese año en carta dirigida al lugarteniente general del reino y al portavoz del gobernador general, así como al justicia de la villa, bajo pena de dos mil florines ${ }^{18}$.

A veces, el monarca dispensaba su protección especial a alguna persona contra la violencia de estas banderías, tal como vemos en la disposición de Martín el Humano del 26 de septiembre de 1409 por la que decreta la protección real para Vicent Marí, de Orihuela, su hermano Antoni Marí, y para Joan Pérez, vecinos de la villa, sus mujeres, hijos y bienes, frente a cualquier agresión de que fueran objeto por causa de los bandos existentes, disposición que debían respetar todas las autoridades ${ }^{19}$. Por otra carta de ese mismo día autorizaba al citado Vicent Marí y a otras dos personas que escogiera, a llevar armas prohibidas de día y de noche por Orihuela y las otras villas y ciudades reales.

La Corona, gracias a la red de fidelidades, que le permitía imponer el arbitraje entre las partes implicadas, fue la única institución capaz de poner paz en la lucha de banderías. A finales de la Edad Media la nobleza urbana

\footnotetext{
${ }^{17}$ ARV, Real, 82, ff.. 49 r-v. 5-12-1440, Valencia.

${ }^{18}$ ARV, Real, 111, f. 13 v-14 r. 27-10-1474, Barcelona.

${ }^{19}$ ACA, reg. 2207, ff. 191 v-192 r. 26-9-1409, Barcelona.
} 
valenciana, en particular en las ciudades medianas, no ofrecía grandes diferencias en cuanto a sus recursos, había bastante igualdad entre ellos, por lo que las luchas de banderías no conducían a soluciones definitivas. En cambio estos desórdenes causaban graves perjuicios a ciudadanos y vasallos, y aunque la guerra era el rasgo distintivo, la ocupación esencial de la nobleza, tales enfrentamientos amenazaban su propia hegemonía como clase social. Pero también perjudicaban a la Corona, inmersa en importantes empresas exteriores, como la expansión mediterránea; a los burgueses, que necesitaban paz para el comercio, y a los campesinos. De ahí que se fuera difundiendo la idea de resolver las diferencias en los tribunales, por la vía judicial, mediante al arbitraje de la Corona y de los oficiales reales, auspiciado todo ello por la difusión del Derecho romano, aunque ello chocaba con los privilegios que los Furs reconocían a los miembros del estamento militar ${ }^{20}$. No obstante, Jaime I ya se reservó mecanismos jurídicos que limitaran la guerra de los nobles, teniendo potestad para "dictar treguas y seguridades de obligado cumplimiento entre caballeros o particulares que se encontraran en guerra" 21 .

A fin de poder defenderse frente a posibles agresiones externas por parte de otras personas, la sociedad valenciana bajomedieval desarrolló la institución de la pau e treua, bien estudiada por R. Ferrer Micó. El objetivo de la institución era introducir un elemento de concordia en la sociedad, aquejada por graves tensiones sociales. Los Furs, en su concepción romanista, no admitían la venganza personal, pero nuestro derecho foral lo que hizo fue conjugar las dos tendencias, la venganza personal como medio para perseguir al delito, y el procedimiento judicial en manos de la justicia, a través de la institución de la paz y tregua. Ante el gobernador o el justicia local ambas partes se comprometían a no hacerse daño en las personas o bienes, siendo responsable ante la parte contraria la que rompiera el pacto. En Valencia se anotaban en los libros de paces y treguas por el justicia, de acuerdo con la disposición dada por Alfonso V en Valencia el 3 de noviembre de 1427. La duración de la misma era variable desde unos meses o un año a la paz final y perpetua, la más deseada por las autoridades, como ya hemos visto en los bandos de Orihuela o de otras localidades ${ }^{22}$. Valga como ejemplo la paz que firmaron el 11 de mayo de 1493 en presencia de Martí Joan Pérez de Requena, justicia de Cocentaina, las dos partes enfrentadas, constituidas por los hermanos Joan y Bernat Prats, y Miquel Alberola, pelaires, de un lado, y Alfonso de Alcaraz, maestro albañil, y Bertomeu Ordonyo, terciopelero, su cuñado. Se trataba de acabar con los debats, bregues, hoüts, rancors e males voluntats y en el acuerdo intervinieron parientes, amigos y valedores, como

\footnotetext{
${ }^{20} \mathrm{C}$. LÓPEZ RODRÍGUEZ, Guerras privadas nobiliarias y paz pública en el reino de Valencia (1416-1458), "Homenaje a Àbilio Barbero", Madrid, 1997; C. LÓPEZ RODRÍGUEZ, Nobleza y poder político. El reino de Valencia (1415-1446), Valencia, Universitat, 2005, p. 196.

${ }^{21}$ C. LÓPEz RodRÍGUEZ, Nobleza y poder político, pp. 197-198. En las pp. 197-203 analiza con detaile la paz pública en el reino de Valencia a fines de la Edad Media.

${ }^{22} \mathrm{R}$. FERrERo Micó, "Pau e treua" en Valencia, "Estudios dedicados a Juan Peset Aleixandre", Valencia, Universidad, II, 1982, pp. 1-15
} 
se especifica en una fórmula ya estereotipada, y se comprometían a no hacerse daño en personas y bienes, bajo la pena de traición, según los fueros de Aragón y Valencia, así como de la Costum de Catalunya, además de cien florines que abonaría la parte transgresora a la otra. Las autoridades locales se mostraban a menudo impotentes para hacer frente a la violencia de los bandos y ni siquiera cabía confiar mucho en la actuación de la justicia, dada la implicación de sus agentes en tales conflictos, lo que ha llevado a R. Narbona a hablar de "cuasi-legitimidad de la violencia nobiliaria" ${ }^{23}$. De ahí que el rey y el gobernador se conviertan en piezas claves para segurar la paz ciudadana, bien citando a los cabezas de los linajes enfrentados, bien imponiendo penas ejemplares, como hizo con Ramón Rocafull que no se salvó de la muerte ni por el prestigio de su linaje ni por los servicios prestados a la monarquía. Lo habitual, sin embargo, es que el rey les concediera su perdón en atención, precisamente, a los servicios prestados, como hizo con Francesc y Joan Soler, acusados de matar a un miembro de la familia Rocafull.

\section{BANDOS EN ORIHUELA}

En la formación de las banderías en Orihuela, además de las características generales ya mencionadas, hay que tener presente también el carácter fronterizo de la villa, lo que dio lugar a una sociedad militarizada, en la que la nobleza fue recompensada con diversos privilegios por Jaime II tras su incorporación al reino de Valencia a cambio de mantener caballo y armas. En el término existían cuatro aldeas de realengo -Catral, Almoradí, Callosa y Guardamar-, y dos señorios baronales, la Daya y Albatera, amén de otros menores. Como señala J.A. Barrio desde la segunda mitad del XIV el acceso a las magistraturas municipales va a quedar reservado a esta elite militar, al margen de su condición jurídica, caballeros o ciudadanos que fueron los "que poseían el privilegio de convertirse en elite política de la ciudad", en la detentadora de los oficios municipales ${ }^{24}$. Otro tanto sucedería en Alicante. En Orihuela en el periodo entre 1416 y 1458 aparecen 153 apellidos en los oficios municipales, aunque sólo veintidós acapararon cuatrocientas veintitrés presencias, más de la mitad sobre el total de 800 presencias contabilizadas. En los caballeros destacan los miembros del linaje Martí con 46 presencias y los Masquefa con 31, Rius, 22; Terrés, 21; Soler, 19; Monsí 18; Togores 14; Miró 13 y Silvestre, 12. En los ciudadanos tenemos a los Rocamora con 42; Pérez con 26; Manresa, 21; Roiç 18, etc. Aquí no se cumplía el fuero que prohibía ocupar el cargo a quien acababa de desempeñarlo y la oligarquía local utilizó las diferentes mecánicas electorales fijadas por la Corona para

\footnotetext{
${ }^{23}$ R. NARBONA VIZCAínO, Violencias feudales en la ciudad de Valencia, "Revista d'Història Medieval", 1, Valencia, 1990, p 77.

${ }^{24}$ J.A. BARRIO BARRIO, Las élites políticas urbanas en la Gobernación de Orihuela. Los sistemas de creación, acceso y reproducción del grupo dirigente en un territorio fronterizo, "Anuario de Estudios Medievales", 32/2 (2002), p. 784. 
reproducirse en el poder, en particular la graduación o matriculación de todos los vecinos con caballo y armas tras instaurarse la insaculación en $1445^{25}$. Ello se tradujo en el hecho de que sólo ciento veinticinco vecinos pudieran acceder a ejercer los oficios municipales, consagrándose la estratificación sociopolítica de la sociedad oriolana, ya que sólo los caballeros y ciudadanos mayores accedían a las principales magistraturas, lo que de inmediato generó protestas entre los que aspiraban a insacularse en la bolsa de ciudadanos mayores. Para la Corona este sistema insaculatorio le permitía una mayor intervención en el gobierno municipal y el disponer del poder de arbitraje en los conflictos suscitados entre las banderías enfrentadas por el acceso y control de las magistraturas municipales.

Los linajes oriolanos y de otras villas del mediodía del reino, cualquiera que fuera su origen - vieja nobleza, nobleza de servicio, ciudadanos, etc.- conservaron siempre un carácter familiar y no formaron partidos. La forma como estos grupos políticos aparecen citados en los documentos reales y municipales refleja sus principales caracteres, su composición y la jerarquía interna entre sus miembros. Además de ser calificados -no muchas veces- como bandos, siempre aparece el nombre del jefe seguido de variadas fórmulas como "sus parientes y sus amigos", "sus hombres y sus aliados", etc. El nombre de la familia permitía distinguir las facciones y los linajes enfrentados.

Junto al jefe encontramos a sus vasallos, que disponían de caballeros. Luego estaban los criados, término que encubre una realidad compleja: desde simples domésticos a compañeros de armas. Formaban una clientela que en tiempo de crisis podía entrar al servicio de un gran señor, que les proporcionaba cargos, rentas y honores, a cambio de participar en las luchas políticas, actuando como hombres de acción en las banderías. A ellos se agregaban "los amigos y aliados", es decir los partidarios, entre los que había vecinos de la localidad, y de este modo los lazos de vecindad repercutían en la solidaridad del bando, al margen del nivel económico de sus miembros.

Estas facciones carecían de un verdadero programa político, lo que explica la variedad de aliados de circunstancia, de todas condiciones y de intereses muy diversos, y "amigos" ocasiones, explicando su inestabilidad y corta duración. En apariencia estos bandos oriolanos no poseían ninguna organización propia ni ninguna estructura política regular y estable. No había signos, vestidos, distintivos, etc., que distinguieran un bando de otro.

Hablar de banderías en la inicialmente villa y luego ciudad de Orihuela es referirse a las principales familias de la oligarquía local: los Rocamora, Rocafull, Miró, Masquefa, Maça, Simón, etc, una nobleza que en la mayoría de los casos hundía sus raíces en los Repartimientos posteriores a la conquista del reino de Murcia desde la segunda mitad del siglo XIII, poseedora de señoríos, grandes fortunas y prestigio, que buscaba el control del

\footnotetext{
${ }^{25}$ J.A. BARRIO BARRIO, La intervención real en la ciudad de Orihuela a través de la implantación de la insaculación. 1445 , "XV Congreso de Historia de la Corona de Aragón", (Jaca, 1993), Tomo 1, Volumen 2, Zaragoza, 1996, pp. 23-34. 
poder municipal o territorial y la defensa y engrandecimiento de su nombre. A costa muchas veces, claro está, de las familias rivales, lo que llevó a una espiral de violencia casi tan antigua como el mismo poblamiento cristiano, aunque no tengamos datos para el siglo XIII. Las noticias más antiguas que hay de estas parcialidades en la entonces villa del Segura son de comienzos del siglo XIV, durante la lugartenencia de procurador en las tierras situadas más allá de Jijona a cargo de Berenguer de Puigmoltó. En efecto, ya el 4 de diciembre de 1305 Jaime II ordenaba al procurador Gombáu d'Entença o al justicia de Orihuela y a Ferrer Descortell, que procedieran contra los responsables de la lucha de bandos, y poco después, el 25 de marzo de 1306, el Consell de Orihuela hizo saber al rey Jaime II que el citado Puigmoltó, alcaide del castillo y lugarteniente del procurador Gombáu d'Entença, que iba a la corte a exponerle la situación del territorio -recién incorporado a la Corona de Aragón y reino de Valencia- le había servido lealmente y estaban contentos con él, ya que no les habían molestado, ni él ni sus hombres habían cometido robos en casas y huertas -algo que sería habitual- y no había tomado partido por los bandos que habían dividido la villa a finales de 1305. El enfrentamiento fue entre Guillem de Togores con Guillem de Paratge, al que desafió, siendo expulsado Togores por Ferrer Descortell, baile general de las tierras de más allá de Jijona. Sin embargo, Togores regresó del exilio y mató a dos bueyes de Guillem de Paratge, lo que encendió de nuevo el choque entre ambos linajes. La situación se complicó por la intervención de elementos foráneos, como fue Diego García, canciller del rey de Castilla, que apoyaba a Guillem de Paratge y a su bando, comprometiéndose a acogerlos y a defenderlos. Para los castellanos, dueños hasta hacía poco de aquellas tierras del reino de Murcia, azuzar la discordia en el territorio que habían perdido no hacía sino favorecerles, e incluso se podría esbozar el enfrentamiento como un choque entre "aragonesistas", los Togores, y "castellanistas", los Paratge. Lo cierto es que Jaime II encargó el 4 de diciembre de 1305 a Gombáu d'Entença, su procurador, o a su lugarteniente, al justicia de Orihuela y al baile general Ferrer Descortell que procedieran contra los responsables de este enfrentamiento de bandos.

En 1308 seguía en pleno vigor el choque entre los Togores y Rossell, que, según era habitual, se intentó resolver mediante un duelo personal, tal como se desprende del reproche hecho por Jaime II a Pero López de Rufes, lugarteniente de Sexona enllà, por haber aceptado el papel de garante o juez del combate que pretendían llevar a cabo Pere Rossell y Guillem Togores, dado que no era costumbre que lo efectuaran los oficiales reales, por lo que le ordenó su renuncia ${ }^{26}$.

La actuación de Berenguer de Puigmoltó fue muy hábil, ya que concertó matrimonios entre las partes a fin de cicatrizar las heridas y todavía en 1314 persistía en esta actitud pacificadora, en este caso entre los bandos de los Togores y los Rossell. En 1316 trató de casar a su nieta Berenguerona con

\footnotetext{
${ }^{26} \mathrm{ACA}, \mathrm{C}$, reg. 140 , f. 78 v.
} 
el hijo de Guillem de Togores, matrimonio que contaba con el visto bueno del monarca, que estaba dispuesto a dotar a la novia con 200 monedas de oro $^{27}$.

El problema de los bandos era para estas fechas, las primeras décadas del siglo XIV, un mal endémico, como ha señalado $\mathrm{M}^{\mathrm{a}} \mathrm{T}$. Ferrer, quien estudió con todo lujo de detalles la organización de este espacio fronterizo en esta centuria. Las disensiones eran entre los caballeros y hombres de paraje, por un lado, y los hombres de villa (homes de vila), por otro, y estaban originadas por el debate sobre la conveniencia o no del acceso al estamento nobiliario a los cargos municipales. Esta era, sin lugar a dudas, la principal causa de las banderías en todas las ciudades de la época, y, como dice Bellot, casi todos los principales de la villa estaban encontrados siguiendo los unos una parcialidad y los otros la otra ${ }^{28}$. La citada autora hizo un minucioso análisis del proceso en la villa de Orihuela, que va desde la aceptación de la exclusión hecha en 1308 por los caballeros y hombres de paraje, a las violencias de los años siguientes ${ }^{29}$.

La realidad es que los caballeros estaban divididos en bandos y en la primavera de 1313 el bando de Guillem de Togores y el de Bernat Rosell, rector de la parroquia de Santa Justa, protagonizaron una batalla armada en plena villa de Orihuela. Desde el 2 de mayo de 1313 Arnau de Torrelles era gobernador del reino de Valencia más allá de Jijona, y pocos días después, el 7 de mayo, Jaime II le pidió que pusiera paz entre dichos bandos. Bernat fue desterrado de la villa. En otra misiva dirigida al justicia de Orihuela y al Consell oriolano les notificaba dicha misión de Torrelles, que debía además castigar a los culpables de tales desórdenes ${ }^{30}$.

La situación de Orihuela era delicada, no sólo porque suponía un peligro para la paz ciudadana, sino por la condición fronteriza de la villa, con Castilla/Murcia y con el reino de Granada. En julio de 1313 Arnau de Torrelles tomó posesión del castillo oriolano y comenzó a ejercer personalmente su autoridad en la pacificación de los bandos de los Togores y los Rossell. Por un lado estaba peleados Guillem de Togores y por otro Francesc Ballester y Domingo de Tona. La tensión se agravó en el mes de octubre y tuvo que intervenir el monarca, convocando en su corte a Alemany y Arnau Rossell y a Guillem y Felip de Togores. Los Rossell habían denunciado ante la corte del justicia oriolano a los Togores por los daños causados a Bernat Rossell y a García Sancho de Yétora.

No sabemos si las partes implicadas acudieron a la corte real, pero en febrero de 1314, como recoge $\mathrm{M}^{\mathrm{a}} \mathrm{T}$. Ferrer, se había llegado a un acuerdo merced al arbitraje de Berenguer de Puigmoltó. No conocemos los términos

\footnotetext{
${ }^{27} \mathrm{M}^{\mathrm{a}} \mathrm{T}$. FERRER I MALLOL, Organització i defensa d'un territori fronterer. La Governació d'Oriola en el segle XIV, Barcelona, CSIC, Institució Milà i Fontanals, 1990, p. 68.

${ }^{28}$ P. BELlOt, Anales, tomo. II, $1^{\text {a }}$ parte, p. 98.

${ }^{29} \mathrm{M}^{\mathrm{a}} \mathrm{T}$. FERRER I MALLOL, Discòrdies entre la petita noblesa urbana i els homes de vila a les terres meridionals valencianes en el primer terç del segle XIV, "Anuario de Estudios medievales", 29, (1999), pp. 301-314.

${ }^{30} \mathrm{M}^{\mathrm{a}}$ T. FERRER I MALLOL, Organització i defensa d'un territori fronterer, p. 85.
} 
del pacto, pero Jaime II exigió su cumplimiento a los Togores y los Rosell, además de a los hermanos Guillem y Pascual de Berga y a Domingo de Tona, representantes de los hijos del difunto Guillem de Paratge, que también intervinieron en las parcialidades.

A pesar del pacto, no hubo paz en la villa y en junio Arnau de Torrelles prohibió a los componentes de dichos bandos entrar en Orihuela. Una nueva ola de violencia se tradujo en el asesinato de Ramón de Togores, del que fueron culpados los hermanos Arnau y Alfons Rossell, que fueron condenados a muerte en ausencia, dado que habían huido de la villa. Con el tiempo, en marzo de 1320, consiguieron que se les perdonara dicho castigo y se les realizara un nuevo juicio. Este año de 1320 marcó el final, por el momento, de las peleas entre ambos bandos, firmándose un acuerdo, aprobado por el rey, en el que se incluía la remisión de todas las penas anteriores y de los procesos incoados contra los implicados.

Los caballeros y hombres de paraje, marginados del gobierno local, volvieron a la carga en 1326 intentando poder acceder al cargo de justicia de la villa, esencial para la defensa de sus intereses, hasta entonces muy perjudicados, y en diciembre de 1325 en el Consell general de la villa, en el que participaban todos los vecinos, hicieron una propuesta para que miembros de estos grupos pudieran ser elegidos para el cargo de justicia, elección que hasta la fecha estaba llena de irregularidades y sobornos. La propuesta la hizo el ya conocido rector de Santa Justa, Bernat Rosell, cabeza de uno de los bandos nobiliarios, siendo bien acogida por parte del pueblo. No pensaba lo mismo la oligarquía local, que controlaba el Consell, que se unió en una liga contra los caballeros y hombres de paraje, que pedían al monarca el envío de un justicia forastero para garantizar su imparcialidad. Existía, además, el riesgo de una revuelta urbana, como la que había estallado en 1325 en la vecina Murcia contra el odiado don Juan Manuel. Se produjeron cruces de misivas y de mensajeros entre las partes afectadas y la corte real, interviniendo además el portavoz del procurador real de las tierras de más allá de Jijona, intentando evitar que el Consell enviara sus mensajeros al rey, provocando la queja de los caballeros y la desautorización del funcionario.

Al final estalló la violencia entre ambos estamentos y el 15 de abril de 1326 una coalición de vecinos atacó y asaltó a mano armada la casa de Llorenç Fritós, entonces ausente como mensajero en la corte. Este Fritós debía pertenecer al estamento de los caballeros y tenía un pleito pendiente con otros vecinos de Orihuela, entre ellos Bernat y Alfonso Rosell, Pere Figuera, Joan Masquefa, Lope García de Ayala, García Gómez y Gonçal de Vilafranca. El rey ordenó al justicia de la villa que castigara tales excesos y expulsara de la villa a Bernat Rossell, rector de Santa Justa y cabecilla de la revuelta. No era la primera vez que cumplía destierro, pero siempre regresaba a Orihuela gracias a la condescendencia de los anteriores justicias. La medida tardó en hacerse efectiva, pues previamente Guillem Ramón de Montcada intentó, infructuosamente, establecer las paces entre Fritós y Rossell. Este último, a pesar de haber sido desterrado, fue autorizado el 5 de septiembre a residir en el término oriolano, gracias a la mediación del infante Pedro, lo que 
indica sus excelentes contactos a nivel de la corte o de la Iglesia, pues también el obispo de Valencia intervino a su favor en otra ocasión. El 13 de diciembre Jaime II le autorizó a regresar a Orihuela, pues tras la sentencia arbitral que pronunció terminaron las discordias entre los bandos, lo que aprovechó el monarca para reformar las instituciones municipales oriolanas, suprimiendo el Consell general y creando un Consell restringido de cuarenta consejeros, y regulando la elección del justicia, de forma que caballeros y hombres de paraje tuvieron acceso al cargo ${ }^{31}$.

Conforme avanzaba la centuria se fue consolidando la posición de la nobleza, sobre todo durante el señorío del infante Fernando y la guerra de los "dos Pedros", acaparando cargos en el gobierno municipal y la tenencia de fortalezas. Los Togores, Rocafull, Soler, Liminyana, Martí Mirón, Masquefa, Rius, Silvestre, Monsi, etc. son apellidos que se repiten en los oficios municipales y de la procuración.

Son nombres que protagonizarán las banderías locales en esta segunda mitad del siglo XIV, de las que tenemos noticia a partir del año 1383, fecha en que Bellot comienza su narración. Por entonces los protagonistas de estas guerras urbanas eran las familias de Guillem de Rocafull, hijo de Ramón de Rocafull, y la de Pere Miró ${ }^{32}$. El linaje Rocafull ocupó desde fecha muy temprana cargos públicos de importancia, como el de procurador general (en 1355), y era uno de los 50 ricos hombres. Ramón de Rocafull era señor de Albatera, mientras que Francesc Miró, lo era de Redován. Digamos que en estas luchas estaban implicados también los oficiales públicos, como el justicia Jaume Despuig, o el baile Francesc Miró, y que el problema no era nuevo, sino algo crónico que se arrastraba varios años con muertes y heridos, hasta que el asesinato de Fernando de Rocafull, "caballero de mucho valor y virtud", a manos de Francesc y Joan Soler, generalizó la violencia en el territorio, obligando al rey a enviar al caballero catalán Narcís Albert como mediador para apaciguar los bandos. Este personaje fue nombrado justicia local, a fin de garantizar la neutralidad del citado oficio, a cuya elección había renunciado el Consell. Este sistema de escoger a alguien forastero, ajeno a los bandos, fue habitual en estos años, a fin de limar las tensiones existentes, intervención que no era del agrado de la oligarquía local. También se recurría a llamar al gobernador general, con frecuencia ausente de la villa, para que impusiera la paz en la localidad. La firma de treguas siempre iba acompañada de la imposición de penas a la parte transgresora, siendo sumas muy elevadas, que no siempre podía satisfacer alguna de las partes implicadas, lo que motivaba quejas al rey, sin que, por lo demás, tales penas fueran un freno a la violencia de las partes. En el caso que nos ocupa Francesc y Joan Soler

${ }^{31}$ J.A. BARRIO BARRIO, La mecánica electoral en la villa de Orihuela (1308-1326), 1490: en el umbral de la Modernidad, Valencia, 1994, II, pp. 3-12.

${ }^{32}$ Con Rocafull estaba Lope Álvarez de Espejo y su hermano Juan Álvarez, Fernando Rocafull y Bernat Ribas, escudero de don Ramón, con sus deudos y valedores. De la parte de Pere Miró figuraba Francesc y Andreu Miró Arnau Masquefa. Simó y Andreu Miró, menor y a todos ellos seguían Francesc y Jaume Soler. Guinés y Guillem Orumbella, Miquel Sicilia, Francés Llorens, Talavera, el hijo de Roca y Perico Miroo. P. BELlot, Anales, II, p. 98. 
fueron desterrados y hubieron de abonar una multa en dinero, pero la sanción sólo la cumplieron hasta la muerte de Pedro IV, pues su sucesor, Juan I, perdonó a los inculpados

En la década de los ochenta del siglo XIV Orihuela estaba sacudida por las luchas entre los bandos de los Rocafull y los Miró, agravadas por la ausencia de la villa en 1384 de Bernat de Senesterra, gobernador general del reino de Valencia más allá de Jijona, por lo que Pedro IV nombró para sustituirle en su ausencia a Berenguer Ripoll. El 13 de julio el rey ordenaba al gobernador, baile y justicia de Orihuela que procediera a suspender desde ese día hasta el próximo marzo toda ejecución contra el noble Ramón de Rocafull, acusado con otros de bandosidad y de haber dado muerte a Joan Pere, de Orihuela, razón por la que estaba preso ${ }^{33}$.

El citado noble, era la cabeza de uno de los bandos implicados, el de los Rocafull, y ese mismo 17 de julio el monarca ordenaba a las mencionadas autoridades que, para conseguir la pacificación de la villa, entre Ramón de Rocafull y sus parciales, de un lado, y Francesc Miró y los suyos, del otro, había dispuesto en carta anterior el sobreseimiento de cualquier pena civil o criminal referente a las muertes cometidas en ambos bandos. Pero luego se enteró que Simó y Andreu Miró, Miquel de Cecilia, Francesc Guillem, Lorenç Calavera, Jaume Roca, Perico Miró, Genís Silvestre y otras personas de dichos bandos, acusados de la muerte de Ferrando de Rocafull y de Joan Pérez, estaban presos en poder del gobernador, que les exigió fianzas. Pedro IV, a pesar de la carta anterior, dispuso que los culpables de tales muertes fueran castigados según disponían los fueros ${ }^{34}$.

Este año se produjo un hecho violento de particular gravedad que fue la pelea de Ferrando de Rocafull y En Miranbell, de un lado, y de Joan y Francesc Soler, del otro. De resultas de la pelea falleció Ferrando, huyendo los agresores, quienes pagaron, según el fuero de Valencia, la pena del citado homicidio al fisco y a la parte injuriada. Sin embargo, pasados quince o dieciséis meses del la muerte, Simón Miró, Miquel Sicilia, Francesc Guillem y En Roca seguían en prisión acusados de dicho homicidio, a pesar de haber quedado claro que ellos no fueron culpables y que ya se había hecho justicia, sin que sus alegaciones de inocencia fueran escuchadas por las autoridades, razón por la que no tuvieron más remedio que acudir a Pedro IV pidiendo justicia. El 27 de septiembre de 1385 el rey de Aragón ordenaba al justicia de Orihuela que finalizara la inquisición contra los reclamantes, haciéndola pública, y si consideraba que dejando fianzas podía ponerlos en libertad, que lo hiciera ${ }^{35}$.

La lucha de bandos entre los Rocafull y los Miró no cesaba en 1386, y el 17 de julio Pedro IV recordaba al gobernador general de Orihuela y al justicia de la villa que, con el fin de conseguir la paz entre Ramón de

\footnotetext{
${ }^{33}$ ACA, C, reg. 943, f. 167 v. 13-7-1384, Monasterio de Poblet.

${ }^{34} \mathrm{ACA}, \mathrm{C}$, reg. 853, ff. 47 v-48 r. 17-7-1386, Barcelona.

${ }^{35}$ ACA, C, reg. 843, ff. 176 v-177 r. 27-9-1385, Girona.
} 
Rocafull, señor de Albatera, y Francesc Miró, señor de Redován, y sus respectivos bandos, en otra carta anterior, del 11 de noviembre de 1385, había dispuesto que durante un tiempo se sobreseyera cualquier pena civil o criminal referente a las muerte cometidas por dichos bandos. Los comprometidos darían fianzas de no salir de la villa ni de la gobernación. Ahora se había enterado de la prisión por el gobernador de Simó y Andreu Miró, Miquel de Cecilia, Francesc Guillem, Lorenç Calanda, Jaume Roca, Perico Miró, Ginés Silvestre y otros, acusados de matar a Ferrando de Rocafull y a Joan Pérez (del bando de los Miró), contra quienes dispuso el rey que fueran castigados según preveían los fueros, si eran encontrados culpables ${ }^{36}$.

Por otra carta posterior, del 6 de agosto, sabemos que la tregua había sido firmada el 11 de noviembre de 1385 en Girona con una duración de un año, y ahora se notificaba a las autoridades de la gobernación y locales que había sido prorrogada por un año más. Dicha tregua se pregonaría por la villa, castigándose con una pena de mil libras a quienes la transgredieran ${ }^{37}$. En una misiva del 24 de octubre dirigida al archipresbítero de Orihuela, el rey de Aragón le pedía que para favorecer la tregua anulara los procesos incoados contra Ginés Silvestre y Pere Miró, del bando de Francesc Miró, ambos clérigos tonsurados, que estaban acusados de cometer muertes y otros delitos.

La intervención de la Corona se dirigía a lograr la paz perpetua entre las partes implicadas, por lo que el 15 de abril de 1387 confirió plenos poderes a Lope Eximén de Perencisa, doncel, quien había trabajado a fondo para conseguir dicha paz, y a Narcís Albert, justicia de Orihuela, dado que ambos eran personas de fuera de la villa ${ }^{38}$. El compromiso debía firmarse ante la reina Violante y los citados árbitros podrían proceder con penas civiles y criminales contra los que alteraran la paz, obligándoles a depositar seguridades y otras obligaciones, incluyendo el juramento y el homenaje $\mathrm{e}^{39}$.

No tenemos noticia de la firma de tan ansiada paz de forma general, aunque sí parece que hubo paces parciales, tal como se desprende de la misiva enviada el 15 de abril de 1387 por Juan I a las autoridades municipales, recordándoles que su antecesor en el trono, Pedro IV, había dispuesto que los que no firmaran la paz o tregua voluntaria no fueran admitidos a los oficios concejiles. Algunos integrantes de ambos bandos habían firmado la paz y habían solicitado que se les admitiera a los oficios, por lo que Juan I, teniendo en cuenta que la mayoría había firmado dicha paz y no se les podía perjudicar

\footnotetext{
${ }^{36} \mathrm{ACA}, \mathrm{C}$, reg. 853, ff. 47 v-48 r. 17-7-1386, Barcelona.

${ }^{37}$ ACA, C, reg. 853, ff. 48 r-49 r. 6-8-1386, Barcelona.

${ }^{38}$ Narcís Albert era gerundense y pertenecía a la casa real. En febrero de 1388 una carta de Juan I al gobernador de Orihuela señalaba que al finalizar su mandado como justicia durante tres años, algunos vecinos querían presentar denuncias contra él. ACA, C, reg. 1833, ff. $18 \mathrm{v}-19 \mathrm{r}$. 11-2-1388.

${ }^{39}$ ACA, C,reg. 1923, ff. 83 v-85 v. 15-4-1387, Barcelona. El rey pedía a sus oficiales que se cumplieran tales órdenes con diligencia.
} 
porque algunos mantuvieran una actitud de abierta rebeldía, ordenó al justicia $\mathrm{y}$ jurados que les admitieran a dichos oficios, según era costumbre ${ }^{40}$.

También en algunos casos vemos a miembros de linajes oriolanos participar en las luchas de bandos murcianas, como es el caso en el último decenio del siglo XIV de Ramón de Rocafull, que militaba en el bando de Juan Sánchez Manuel, frente al bando del adelantado Alonso Yáñez Fajardo.

En el siglo XV las cosas no han cambiado en cuanto a los detentadores del poder local y al frente del patriciado local aparecen los Rocafull, Masquefa, Ruiz, Soler, Rocamora, Silvestre, Martí, Arboredes, Ferrández de Mesa, Monsi de Castanyeda, Terrés, Ibáñez de Ruidoms, Rius, Montagut, López de Baena, Pérez Vayllo, Galbe Vilafranca, Rosell, Togores, Gilabert, Orumbella y algún otro linaje conocido. Son las veinticinco familias de siempre, que también figuran entre los ciudadanos mayores.

Graves banderías se produjeron en la villa hacia 1409 por causa de la ocupación de un cargo público, enfrentándose Joan de Ayora, personaje próximo al poder (jurado, obrero de muros, mensajero del Consell, etc.), apoyado por sus familiares y amigos, entre ellos los Monsi de Castanyeda y los Vidal, contra los Pérez, Flavians y Despuig, quienes arrastraron a la lid a varios individuos de las familias Masquefa y Miró, familias todas de la oligarquía local. Recordemos que por entonces Orihuela estaba bastante agitada, pues, una vez más, se dejaban sentir las revueltas en la vecina Murcia, provocadas por la llegada del condestable de Castilla Ruy López Dávalos, adelantado mayor del reino de Murcia, en tanto que Martín I solicitaba a Orihuela un importante donativo para la celebración de su boda, lo que generó un fuerte malestar, dado lo menguado de las arcas municipales.

En vano mediaron Bertomeu Togores, gobernador en funciones, y más tarde el Consell municipal, que había comisionado como pacificadores a los señores de Albatera y Daya. La solución final fue recurrir al rey Martín el Humano para que enviara al gobernador Olfo de Pròxida, quien debería nombrar a un lugarteniente imparcial, mientras que se pedía al monarca que enviara un justicia criminal por el plazo de tres años, durante el cual el Consell renunciaba a su elección. Una vez más vemos el oficio de justicia como centro de la disputa entre los grupos nobiliarios.

El rey nombró como pacificador a Jaume de Aragón, conde de Urgell, al que se añadió Simó Miró, caballerizo y consejero del rey, así como baile general del reino, firmándose una concordia bajo amenaza de fuerte multa y privación de oficios, sin que esta vez corriera la sangre.

Poco duró la paz, pues este mismo año encontramos enfrentados los bandos de los Rocamora y Martí contra las familias de los Terrés y Monsi. El día de Navidad del referido año, terminadas las ceremonias electorales, el justicia civil electo, Pere Rocamora, se hallaba paseando por la lonja de la plaza mayor cuando le abordó Jaume Terrés con el ruego de que renunciase al cargo que deseaba para un amigo. Se resistió Rocamora, discutieron,

${ }^{40}$ ACA, C, reg. 1836, f. 126 r-v. 30-11-1388, Monzón. 
salieron a relucir las armas y acudieron los amigos de los interesados, entre ellos Bertomeu Monsi, que atacó al gobernador Pero Maça, que quiso prenderlo, por lo que Monsi huyó en busca de refuerzos para acabar con el gobernador, al que se consideraba implicado, lloviendo toda clase de injurias contra él. Éste se consideraba dañado en su honra, por lo que tuvo que intervenir el procurador real, Joan Pujalt. Hubo conflicto de jurisdicciones, detenciones, huidas, multas para los comprometidos, hasta que llegó el perdón real, la única fórmula que garantizaba la paz entre las partes.

Es bien sabido que una de las causas que fomentaban las guerras nobiliarias urbanas era la ausencia del poder político, que es lo que sucedió en la Corona de Aragón al fallecer sin herederos en 1410 Martín I. Durante el Interregno en Orihuela las autoridades municipales se mantuvieron neutrales frente a los sangrientos enfrentamientos en Valencia entre los Vilaraguts y los Centelles, lo que no fue óbice para que ecos de estas banderías capitalinas se dejaran sentir en Orihuela, y si Simó Miró, el baile general, militó en el bando de los Vilaragut, su oponente, el gobernador general de Orihuela, Olfo de Pròxita, era uno de los más notables partidarios de los Centelles. Con todo, la nobleza local permaneció tranquila, al margen de las banderías, y aunque se produjo un grave incidente armado entre Joan Soler, designado en 1411 como lugarteniente del gobernador, y Alfons Rosell, lugarteniente del justicia, el gobernador Pròxita pudo mantener la paz ciudadana.

A finales de la segunda década de la segunda centuria se formaron bandos y se produjeron enfrentamientos entre las familias de los Vilaraguts y los Pardo. Tenemos noticia de ello por la carta enviada por Alfonso V el 3 de junio de 1418 a Julià Carreres, Alfonso Pérez y otros de Orihuela para que respetaran la paz que recientemente se había firmado ante el notario Francesc d'Arinyo, por la que cesaban los bandos entre las mencionadas familias oriolanas ${ }^{41}$.

La documentación ya no vuelve a dar noticia de estas guerras urbanas hasta el año 1436, en que varios jóvenes pertenecientes a la más selecta sociedad oriolana - los Martí, Despuig, Molins etc.-, con sus luchas callejeras perturbaron las fiestas del Corpus de aquel año, las más concurridas de Orihuela desde su institución en 1402. Los días de fiesta señalados, como éste, propiciaban los tumultos urbanos, dada la afluencia de gente que facilitaba el encubrimiento y la huída. Hubo injurias y cuchilladas a discreción con fuga de los principales inculpados, mediaciones de Elche y Alicante, y amistosa concordia final.

Este año, el 1 de septiembre de 1436 Juan II, rey de Navarra y lugarteniente general de su hermano Alfonso V, ordenaba a Pero Maça de Liçana, gobernador general de Orihuela que, bajo la pena de 500 florines, pusiera paz en las injurias que mutuamente se vertían Francesc y Jaume Rocamora, de Orihuela ${ }^{42}$.

\footnotetext{
${ }^{41}$ ACA, C, reg. 2590, ff. 51 v-52 r. 3-6-1418, Valencia.

${ }^{42}$ ARV, Real, 266, f. 24 v. 1-9-1436, Alcañiz.
} 
A este enfrentamiento ya "clásico" entre Masquefas y Rocamoras se añadía en 1437 el de los Molins y los Martins. El 7 de junio don Juan, lugarteniente general, que estaba en Valencia, dispuesto a pacificar Orihuela y a poner fin a tales disputas, preparó una sentencia arbitral, en la que habían colaborado y puesto su firma una serie de personas. Ahora pedía que la firmaran Bertomeu Togores, hijo de Jaume Ivanyes, Francesc Molins, Pere y Nicolau Molins, Antoni de Gualbes, Lope Soler, Andreu García de Lasa, Joan Rois, menor, Pere Prats y las madres, tanto de los Molins como de los Martins. Ordenaba al gobernador general que diera un plazo de seis días para que los interesados o sus procuradores firmaran dicho documento, bajo la pena de 1.000 florines $^{43}$. Unos días más tarde, el 27, don Juan guiaba y aseguraba por un plazo de quince días a Bertomeu Togores y a Pere Molins, junto con tres criados de este último, para que pudieran ir sin peligro por Orihuela y su término.

Los Togores y los Molins actuaban unidos frente a los Martíns, como se ve en la misiva dirigida por el lugarteniente general a Pere de Rius, subrogado del gobernador de Orihuela, al que le recordaba que le había ordenado que recogiera información sobre cierto episodio acaecido contra el hijo de Joan Martí por parte de Pere Molins y Bertomeu Togores, junto a otros vecinos de la ciudad, a raíz del cual se interpuso una denuncia. Don Juan, a fin de pacificar la villa, anuló todas las denuncias, incluida la citada, por lo que ordenaba a Rius que dejara de recabar información, quedando cancelado el caso ${ }^{44}$. El sobreseimiento de una instrucción contra los agitadores era una de las medidas habituales puestas en marcha por la autoridad para pacificar la ciudad.

De las banderías en años posteriores no hay muchos datos. Así, sabemos que el 21 de enero de 1443 la reina doña María, lugarteniente general del reino, ordenaba a Pero Maça de Liçana, gobernador de Orihuela, para que a través de Jaume de Rius, bachiller en leyes, oyera las instrucciones que la reina había dado en el asunto de los ataques que algunas personas habían realizado contra los oficiales reales ${ }^{45}$

El 28 de septiembre de 1458 Juan II escribía al justicia y a los jurados oriolanos para que todos los oficiales siguieran en sus puestos hasta que él acudiera a Valencia, donde se encargaría de arreglar y pacificar los asuntos de Orihuela -cuya naturaleza ignoramos-. Dispuso también que Eximén Peris, licenciado en decretos, tuviera la asesoría judicial ${ }^{46}$.

Un vacío de noticias sobre las banderías urbanas se produce hasta finales de la década de los sesenta, aunque no creo que las aguas políticas estuvieran pacíficas. De nuevo el 28 de abril de 1467 vuelve a reaparecer

\footnotetext{
${ }^{43}$ ARV, Real, 67, f. 38 r-v. 7-6-1437, Valencia.

${ }^{44}$ ARV, Real, 66, f. 59 r-v. 30-8-1437, Valencia.

${ }^{45}$ ARV, Real, 261, f. 29 v. 21-1-1443, Tortosa.

${ }^{46}$ ARV, Real, 280, f. 19 r. 28-9-1458, Zaragoza.
} 
información sobre bandos en Orihuela, cuando Juan II ordenó a mosén Pere Masquefa, Francesc Silvestre y Nicolau Orumbella, que pronunciaran sentencia en el pleito movido entre mosén Jaume y mosén Joan Rocamora, de un lado, y mosén Antoni Amorós, del otro, por contravenir la orden dada a Jaume Rocamora para que no entrara en la ciudad y a mosén Joan para que se fuera a su heredad ${ }^{47}$.

La más cruenta de estas banderías nobiliarias tuvo lugar en 1468. Cierto día se registró una pelea callejera entre individuos jóvenes de las familias Rocamora y Talavera, de la que resultaron algunos heridos y contusos. Los Rocamora inculpados se pusieron a salvo en Elche. Algún tiempo después marchaba desde Novelda a Orihuela Ramón de Rocafull, señor de Aspiella y subrogrado del gobernador. Iba en compañía del alcaide de Callosa, mosén Antoni Amorós, de otro individuo y de sus mujeres. El primo y homónimo de Rocafull, señor de Albatera y lugarteniente del gobernador, había recabado su presencia en la villa para contribuir a la pacificación del territorio. Al pasar cerca de Elche, les salieron al paso los Rocamora prófugos y cayeron por sorpresa sobre los viajeros, dándose a la fuga después de matar a Rocafull y al alcalde, refugiándose en Aspe, cuyo baile, Joan de Vargas, les apoyaba.

Un baño de sangre fue la respuesta de los Rocafull. Mosén Jaume Rocamora, jefe de la familia y ajeno a lo ocurrido, fue sorprendido y muerto en cierto camino cuando viajaba desarmado en compañía de un criado. Las casas de los Rocamora fueron asaltadas por el bando rival. Un sobrino de mosén Jaume, convaleciente en el lecho, fue asesinado, en tanto un tío suyo pudo escapar herido, evadiéndose por un tejado.

El 25 de octubre de 1468 Juan II ordenaba a Pero Maça de Liçana, gobernador general de Orihuela, que suspendiera cualquier proceso de ausencia iniciado contra Joan de Rocamora, refugiado en Elche, mientras estuviera enfermo, como consecuencia de las heridas que le causaron Lluís de Rocafull, hijo del lugarteniente del gobernador, y Onofre de Rocafull, quienes con mucha gente armada asaltaron la casa de Joan de Rocamora, donde estaba arrestado por la muerte de Jaume de Rocamora ${ }^{48}$.

Tras la muerte de mosén Ramón de Rocafull y de mosén Antoni Amorós, mosén Joan Rocamora puso su persona a disposición del rey. El 5 de noviembre de 1468 Juan II notificaba al gobernador Pero Maça de Liçana y a las autoridades municipales que había sobreseído cualquier proceso contra Joan de Rocamora, ordenándoles que le devolvieran todos los bienes, trigos, libros, escrituras y cualquier otro bien suyo o de su difunto padre, Joan de Rocamora, que le hubieran embargado, bajo la pena de 5.000 florines en caso de no cumplir su orden ${ }^{49}$. El día 16 de este mes Joan de Rocamora, caballero, se comprometió a depositar ante el monarca y su corte dichos bienes cuando

\footnotetext{
${ }^{47}$ ARV, Real, 291, f. 11 r. 28-4-1467, Tarragona.

${ }^{48}$ ARV, Real, 291, f. 76 r-v. 25-10-1468, Zaragoza.

${ }^{49}$ ARV, Real, 292, ff. 45 v-46 r. 5-11-1468, Zaragoza.
} 
le fueran requeridos, dejando como fiador a Jaume Fernández, doncel de Elche.

La situación había alcanzado tal grado de deterioro del orden y la autoridad pública que Juan II ese día notificaba al baile general del Orihuela, Jaume Roca, que había escrito al gobernador oriolano para que tales crímenes no quedaran impunes y que enviaría a su hijo primogénito para administrar justicia. Con el fin de pacificar la situación nombraba a Roca lugarteniente del gobernador, a la vez que ordenaba al citado funcionario que revocara en tal función a Ramón de Rocafull. La implicación del gobernador Pero Maça en estas banderías, apoyando a los Rocafull, era muy fuerte, por lo que el rey disponía que si no se tomaban medidas contra las personas y bienes de Ramón de Rocafull, Lluís de Rocamora, su hijo, y Onofre de Rocafull, primo hermano, que lo hiciera Maça hasta que el infante Fernando aplicara justicia. Disponía también Juan II que se tomaran bienes de los cómplices de estos bandos para escarmiento general, devolviendo los que se habían embargado a Pere Avellà y Joan de Rocamora ${ }^{50}$.

En noviembre el balance de bajas por parte de los Rocafull era el de Ramón de Rocafull, y por el bando de los Rocamora los de mosén Jaume Rocamora, lugarteniente del gobernador, y de su sobrino Joan Rocamora, además del asalto a las casas y heridas en las personas de Pere Avellà, cuya casa resultó asaltada y recibieron heridas él mismo, su suegra y su mujer. También se ocuparon las casas de Jaume Rocamora y su hijo Joan, así como la de su hermano Joan de Rocamora, además de otro Joan de Rocamora, sobrino, desmanes de los que fueron acusados Ramón, Lluís y Onofre de Rocafull junto con sus cómplices. El papel de reivindicadoras de la justicia lo van a ejercer las mujeres del linaje, y a petición de la madre, hermanas, nietas e hijas de los Rocamora difuntos, el 21 de noviembre Juan II ordenaba al gobernador oriolano, Pero Maça, que destituyera de su cargo a Ramón de Rocafull, tal como ya había indicado hacía unos días, tomando y asegurando los bienes de los considerados culpables ${ }^{51}$.

Los Rocamora parece ser que fueron los que llevaron la peor parte, por el momento, y el 10 de diciembre Juan II escribía a mosén Joan Roca, baile general de Orihuela, y a micer Miquel Albert, doctor en leyes de Valencia y a su asesor, encargando a éste que cuando fuera a Orihuela llevara consigo un buen notario para redactar las actas sobre las muertes de los Rocamora. Así mismo, debía poner a buen recaudo a Joan Rocamora con el fin de que no fuera atacado por el bando contrario, devolviendo los bienes de los Rocamora una vez que hubieran depositado la fianza correspondiente ${ }^{52}$. Unos días después, el 15 de diciembre, a fin de poner término a las muertes

\footnotetext{
${ }^{50}$ ARV, Real, 292, ff. 47 r-48 r. 16-11-1468, Zaragoza.

${ }^{51}$ ARV, Real, 292, ff. 48 r-39 r. 21-11-1468, Zaragoza. Este mismo día Juan II notificaba a mosén Lluís Cabanyelles, gobernador general del reino, el envío de las cartas arriba citadas y dirigidas a Jaume Roca y a Pero Maça, con el fin de que las remita con la mayor rapidez con un portero a los interesados.

${ }^{52}$ ARV, Real, 292, ff. 57 v-58 r. 10-12-1468, Zaragoza.
} 
y desórdenes que se venían produciendo en Orihuela a causa de los bandos, Juan II nombró justicia criminal de la ciudad al caballero Jaume Masquefa.

En el conflicto aparece implicado de forma indirecta el gobernador oriolano Pero Maça, quien nunca actuó con la energía y autoridad que requería la grave situación, dada su simpatía por los Rocafull. Era hijo de una Rocafull y poco amigo de los Rocamora, a quienes envidiaba el favor en que les tenía el conde de Concentaina, gobernador general del reino. El 18 de enero de 1469 Juan II le ordenaba que con el fin de poner orden en la lucha de bandos residiera en la ciudad hasta que fuera su hijo, el infante Fernando, contando con el apoyo de mosén Joan Roca, su lugarteniente, y de micer Jaume Deztorrent, abogado de Valencia, al que nombró su asesor. Una vez más, el rey nombraba a personas de fuera de la ciudad, con el fin de conseguir la máxima imparcialidad en sus actuaciones. El rey encargaba también a Pero Maça que con la ayuda de estas personas conociera los pleitos entre Ramón de Rocafull, de una parte, y Jaume de Rocamora y los suyos, y Joan de Rocamora y otros, de la otra parte, suscitados por las muertes habidas en ambos bandos ${ }^{53}$.

Uno de los personajes que aparece implicado con más frecuencia en estas violencias era Joan de Rocamora, aunque el problema es saber de cuál de los que llevaba dicho nombre era el implicado. Sabemos que este Joan de Rocamora había sido arrestado por el justicia de Orihuela a causa de las heridas perpetradas contra otro Joan de Rocamora. Y es que no era infrecuente que miembros de un mismo linaje lucharan en bandos enfrentados. A causa de la muerte de los caballeros Antoni Amorós y Ramón de Rocafull ya vimos como los Rocafull atacaron la casa de Rocamora, quien salvó la vida saltando por la ventana, y aunque se rompió un brazo pudo huir a la vecina localidad de Elche, donde se refugió. El 5 de mayo de 1469 Juan II ordenó a Lluís de Cabanyelles, lugarteniente del gobernador de Orihnuela, que devolviera a Rocamora los bienes que le había confiscado.

A partir de ahora los sucesos prosiguieron en el terreno de la vía judicial, en un proceso contra los Rocafull y valedores. Pere Masquefa expuso al monarca que mosén Miquel Salsola, lugarteniente del gobernador oriolano, y Joan Soler, doncel, habían dado orden y pregonado que nadie acudiera a las casas o heredades de las personas incluidas en el citado proceso, ni que se reunieran por la ciudad en grupos de más de tres personas. También anuló el salvoconducto concedido por el príncipe Fernando cuando éste estuvo en Orihuela, pero parece que tales actuaciones no eran conforme a la ley, por lo que Juan II el 22 de noviembre de este año anuló el primer pregón a la vez que pedía que se respetara el salvoconducto dado por el infante. Y el 19 de diciembre el rey guiaba a Ramón y Onofre de Rocafull.

Los Rocamora continuaron en el exilio hasta que Joan de Rocamora y los otros miembros del linaje obtuvieron, en fecha que desconozco, pero anterior a mayo de 1470 , permiso del monarca para regresar a Orihuela y su

${ }^{53}$ ARV, Real, 292, ff. 64 v-65 r y Real, 291, ff. 107 v-108 r. 18-1-1469, Zaragoza. 
término, autorización que no les fue respetada por el gobernador Pero Maça, que les ordenó salir de la ciudad. Los Rocamora reclamaron a la Corona contra este abuso y el 7 de mayo de 1470 Juan II ordenaba de nuevo al gobernador que les permitiera estar libremente en la ciudad.

Ya dijimos que las banderías eran uno de los mecanismo habituales utilizados por un grupo de la oligarquía local para conseguir que sus rivales quedaran excluidos de los oficios municipales. Como ejemplo podemos tomar el ataque que en estas fechas se dirigió contra Jaume Masquefa, lugarteniente del gobernador general de Orihuela, y estuvo protagonizado por los Rocafull y los de su bando, quienes fueron contra el lugar de la Daya, señorío de los Masquefa, al que cortaron la nariz y las orejas (fonch feta la cisió de nas e orelles), además de incendiar la localidad. El 24 de mayo Juan II ordenaba a los jurados de Orihuela que en las próximas elecciones a jurados y sobrecequiero de la ciudad no fueran admitidas las personas que participaron en dicho ataque $^{54}$. Entre los personajes que quedaron excluidos de las elecciones estaban Francesc Pérez y Jaume Despuig, acusados de intervenir en dichos hechos, pero como había duda sobre su participación, Juan II pidió el 17de julio a Jaume Roca, baile general de Orihuela, que le remitiera información sobre ambos para adoptar una decisión al respecto. Sabemos que los cabecillas de tal ataque fueron Ramón, Onofre y Lluís de Rocafull junto con sus partidarios, que fueron condenados a muerte por tales crímenes. El 6 de julio el rey dispuso que fueran condenados a muerte por ello, debiendo cumplirse la sentencia cuando fueran capturados.

Nada parecía poder calmar la división ciudadana y en el otoño de 1473 todavía proseguían las tensiones, de tal forma que la Corona envió a micer Pere Falcó, abogado, como asesor de mosén Miquel Salsola, gobernador general de Orihuela, para calmar las disputas entre los Rocamora y los Rocafull, con un salario de 20 sueldos diarios, que se abonarían con rentas de la bailía. Lo malo para el interesado es que no le pagaban, por lo que tuvo que reclamar al rey los atrasos del baile general, por lo que el 3 de noviembre Juan II ordenaba a Jaume Roca, baile general, que pagara sin demora tales deudas ${ }^{55}$.

El 9 de enero de 1474 el Consell oriolano, considerando los daños y muertes generados por los bandos entre los Rocafull y los Rocamoras, por servicio a Dios, a la majestad real y para reposo de la ciudad, encargó a los jurados que intervinieran entre ambas familias para conseguir la paz, siendo acompañados en tal misión por las personas que considerasen oportunas, pudiendo enviar mensajeros al rey para conseguir dicha paz, en el caso de que fracasaran sus gestiones ${ }^{56}$.

Otros bandos existentes por estas fechas en Orihuela eran los de los Roca y los Balaguer, de los que nada he encontrado en la documentación

\footnotetext{
${ }^{54}$ ARV, Real, 293, ff. 45 v-46 r. 24-5-1470, Monzón.

${ }^{55}$ ARV, Real, 294, ff. 38 r-39 r. 3-11-1473, Barcelona.

${ }^{56}$ AMO, Actas Capitulares, no 32 . f. 17 r.
} 
municipal. Tan sólo una noticia del 11 de mayo de 1477, fecha en que Juan II ordenaba a micer Francesc de Vilafrancia, justicia criminal de la ciudad, y a micer Pere de Fuentes, abogado fiscal, para que recibieran informaciones en Orihuela, Alicante y otras villas sobre el tumulto que tuvo lugar en Orihuela a raíz del arresto de Joanot Balaguer, debido a un altercado con un escudero del difunto mosén Jaume Roca, que fue baile general de Orihuela, en el que los Roca atacaron a Balaguer y su casa ${ }^{57}$.

La tregua entre los Rocafull y los Rocamora se firmó en el verano de 1477 y a ella se alude en la carta enviada por el rey de Aragón al justicia criminal de Orihuela el 9 de septiembre, en la que se dice que se firmó en días pasados entre Ramón de Rocafull, Onofre de Rocafull e hijos, por un lado, y Joan y Francesc de Rocamora, además de otros Rocamora, por la otra parte, disponiendo que nadie rompiera la tregua, bajo la elevada pena de 5.000 florines $^{58}$.

Es posible que la tregua se prorrogara, pues hay noticia de su finalización el 7 de noviembre de 1479, esperándose graves disturbios una vez terminara. Sabemos que ante el rey acudió Joan de Rocamora y le prestó homenaje y juramento de fidelidad, comprometiéndose a no partir de la corte y presentarse ante él o su vicecanciller cuando le fuera requerido, bajo a pena de 10.000 florines. Los Rocamora solicitaron al monarca justicia de todos los crímenes cometidos, por lo que el 13 de noviembre de 1479 ordenó a Pero Maça, gobernador de Orihuela, que diera un pregón para el mantenimiento de la paz y que nadie hiciera guerra con los Rocamora, utilizando la vía judicial en sus enfrentamientos, a fin de devolver la paz a la ciudad ${ }^{59}$. El objetivo era claro: acabar con las guerras privadas y la venganza de la sangre, primando la vía judicial.

En los años ochenta no hay noticias de estas alteraciones en la documentación municipal y resulta llamativo la consolidación en el gobierno municipal del linaje de los Rocamora. Así, en 1488, por ejemplo, vemos entre los jurados a mosén Joan Rocamora, mayor, a Pere Roca, hijo de mosén Joan Rocamora, menor, y a Pere Rocamora, hijo de mosén Lope Rocamora. En cambio, no aparece ni un Rocafull, y sólo un Masquefa, Galcerà Masquefa.

Volvemos a tener noticias de bandos en la década final de siglo, cuando el 4 de noviembre de 1493 Fernando II comisiona a Juan de Lanuza, justicia de Aragón y lugarteniente general del reino de Valencia, y a Pero Maça de Liçana, gobernador general de Orihuela, que hagan respetar la tregua impuesta en el pasado mes de febrero por Lanuza entre los Masquefa y los Rocafull. La causa del enfrentamiento entre estos bandos era la muerte de Pere Masquefa a manos de Ramón de Rocafull ${ }^{60}$.

\footnotetext{
${ }^{57} \mathrm{ARV}$, Real, 111, ff. 176 r-177 r. 11-5-1477, Tortosa. El rey pedía que, una vez recopilada la información, se la remitieran.

${ }^{58}$ ARV, Real, 114, fol. 112 r-113 r. 9-9-1478, Barcelona.

${ }^{59}$ ACA, C, reg. 3563, f. 18 r-v. 13-11-1479, Toledo.

${ }^{60} \mathrm{ARV}$, Real, 137, f. 39 r-v. 4-11-1493, Barcelona.
} 
Proseguía también el enfrentamiento "clásico" entre los Rocamora y Rocafull. El 4 de junio de 1496 el monarca aragonés encargaba al infante Enrique, duque de Segorbe y conde de Ampurias, lugarteniente general en el reino, que resolviera con justicia las quejas presentadas por micer Jaume de Rocamora, doctor en ambos derechos, en su nombre y en el de su hermanos, parientes y amigos, por los malos tratos y vejaciones llevados a cabo por el gobernador de Orihuela, Pero Maça y su familia, junto con sus aliados los Rocafull ${ }^{61}$.

En las postrimerías medievales la oligarquía local aparece escindida en dos facciones irreconciliables. A su frente aparecen los Maça y Rocafull, que se disputan la máxima magistratura gubernativa, acaparada por los primeros. Los Rocafull cuentan con el apoyo de Masquefas y Rocamoras. Estas tres antiguas familias aparecen más vinculadas a la urbe que los Maça, grandes terratenientes de origen foráneo, cuya ascensión es paralela a la de los Fajardo murcianos y tiene un mismo origen: su apoyo incondicional a los monarcas Trastámara, que les confían el adelantamiento en Murcia y la gobernación en Orihuela. Los Maça mantendrían su primacía hasta bien entrada la Edad Moderna.

\section{BANDOS EN OTRAS LOCALIDADES}

Las guerras urbanas no fueron una exclusiva de Orihuela, ya que incluso en las aldeas dependientes de la villa se reproducían, a pequeña escala tales bandos, como era el caso de Callosa de Segura, que, según nos cuenta P. Bellot en 1423 "estaba dividida en dos parcialidades y el consejo envió a Jaime Masquefa y Antonio de Galbe que los pacificaran, e hicieron las dos parcialidades paz llana" ${ }^{62}$. Nada se dice de las razones de tal enfrentamiento.

De la villa de Elche tenemos también noticia de la existencia de bandos a comienzos del siglo XIV, pues el 2 de junio de 1311 Jaime II ordenaba a Dalmau de Castellnou, portavoz del procurador en el reino de Valencia, que acudiera a Elche a poner paz entre los bandos existentes, y que tomara una resolución sobre la ordenanza hecha en Elche prohibiendo llevar armas, que afectaba incluso a los oficiales reales y que podía resultar muy peligrosa para su seguridad, dada la abundante población mudéjar de la zona, corriendo el riesgo los cristianos, que eran pocos, de ser atacados ${ }^{63}$. Es posible que en estos bandos, como veremos a continuación, estuviera implicado Berenguer de Puigmoltó.

\footnotetext{
${ }^{61} \mathrm{ARV}$, Real, 138, ff. 62 v-63 r. 4-6-1496, Almazán.

${ }^{62}$ Mossén P. BELlOT, Anales de Orihuela (siglos XIV-XVI). Estudio, edición y notas del Dr. D. Juan TORRES FONTES, Oriola Publicaciones del Casino Orcelitano-Patronato Artístico de Orihuela, 1954-56, 2 vols. $505+412$ pp. Vol. I, p. 306.

${ }^{63} \mathrm{ACA}, \mathrm{C}$, reg. 239 , f. 83 r. 2-6-1311, Huesca, Ma T. FERRER I MALlol, Les aljames sarraïnes de la Governació d' Oriola en el segle XIV, Barcelona, CSIC, Institució Milà i Fontanals, 1988, doc. 37, pp. 207-208.
} 
La entonces villa Alicante no escapó a la violencia de los feudales en estas fechas, y el 8 de febrero de 1300, Jaime II, que hacía poco que se había apoderado de la villa, ordenaba a Ramón Sacota y a Jaume Bernat que hicieran una encuesta para averiguar lo sucedido en el asalto a la casa de Berenguer de Puigmoltó ${ }^{64}$. Las peleas y disensiones llevaron a este personaje a hacerse vecino de Elche y como tal lo vemos en mayo de 1311. El 17 de este mes escribía a Jaime II advirtiéndole de que las críticas que le pudieran llegar sobre él se debían a la enemistad que le tenían el baile general, Ferrer Descortell, como Pero López de Rufes, alcalde de la Calahorra de Elche. Tal enemiga se debía a la protección de Puigmoltó a sus cuñados menores de edad, nietos de Bernat Romeo y a su sobrino Betrán de Masdovelles. A ello se añadía el hecho de que había abierto una puerta en Elche y quería dar una llave a los mudéjares de la villa, lo que provocó muchas murmuraciones entre los vecinos ${ }^{65}$.

Décadas más tarde, como recogió $\mathrm{M}^{\mathrm{a}} \mathrm{T}$. Ferrer, tenemos documentados algunos episodios de tales bandos alicantinos. Un buen ejemplo es el que que tuvo lugar en 1369 a raíz del asesinato en los primeros meses de este año del caballero Berenguer Togores, crimen del que fueron acusados Dalmau de Jàfer, caballero y alcalde del castillo de Alicante, Jaume d'Àries, Pere Desvall, Miquel de Nariza y Jaume Medina, vecinos de la villa. Fueron las propias autoridades locales quienes acusaban a Jàfer de participar en dicho asesinato, y así se lo expusieron al monarca en el memorial de agravios que le enviaron, en el que también se quejaban del abandono del castillo por parte de este alcalde. Recordemos que Alicante acababa de salir de la gravísima situación ocasionada por la guerra de los "dos Pedros" y la ocupación castellana, que la dejó poco menos que devastada, por lo que conservar en buen estado la fortaleza y mantener la villa en orden eran preocupaciones esenciales de jurados y consellers. Pedro IV encargó a Nicolau de Pròxita que investigara el caso y si Jàfer era culpable lo apresara. No sabemos el resultado de la pesquisa, pero cabe pensar en una implicación de este personaje en esta lucha nobiliaria, dado que el diciembre fue destituido del cargo de alcalde y sustituido por Joan Mercer ${ }^{66}$.

Los bandos implicados eran las familias de los Togores, de un lado, y los Vallebrera, de otro, con todos sus valedores, y dada la situación fronteriza de la villa el rey ordenó en junio de 1370 al gobernador Nicolau de Pròxida que obligara a las partes a firmar paces y treguas. No era una advertencia vana, pues el rey se había enterado que los caballeros, generosos y otras gentes de Alicante se conjuraban y formaban ligas y manipolis entre ellos para proseguir las luchas de bandos, por lo que en una nueva carta del

\footnotetext{
${ }^{64} \mathrm{ACA}, \mathrm{C}$, reg. 115, f. 228 v. 8-2-1300.

${ }^{65}$ ACA, C, Cartas reales de Jaime II, $\mathrm{n}^{\mathrm{o}}$ 4.024. 17-5-1311, Elche.

${ }^{66} \mathrm{M}^{\mathrm{a}} \mathrm{T}$. FERRER I MALLOL, Organització i defensa d'un territori fronterer, p. 131.
} 
8 de julio al gobernador insistía en que restableciera la paz y castigara a los culpables ${ }^{67}$.

Siguiendo hacia las comarcas del norte hay noticias dispersas de otras localidades, como es el caso de Jijona. Aquí, los bandos no parece que fueran permanentes, sino generados por una circunstancia excepcional, que solía ser el asesinato de algún vecino, lo que provocaba la inmediata reacción grupal de parientes y valedores del difunto contra la otra familia. Lo vemos en la misiva enviada el 30 de diciembre de 1461 por Juan II al justicia y jurados de Jijona con motivo del asesinato cometido en la villa por Joan Bretons contra Pascual Morant, lo que dio lugar a fuertes tensiones entre los parientes de las partes. El rey instaba a las autoridades locales a que forzaran a las partes a conseguir la paz, dado que el asesino había huido y se estaba instruyendo el correspondiente proceso. De no aceptar la paz procedería contra los que la alteraran $^{68}$.

En la cercana Alcoi tenemos constancia de la existencia de bandos en el siglo XIV y en los libros del justicia local del año 1340-1341, Guillem Pujades, se aprecia la preocupación de las autoridades por la alteración del orden público a causa de las banderías entre Ponç Sisternes, su hijo y sus amigos, de una parte, y Pere Corregir y Simó Guardiola con sus hermanos y parientes, de la otra parte. Todos iban armados y se corría el peligro de que los enfrentamientos causaran víctimas mortales, por lo que el justicia convocó a las partes, las amonestó y las amenazó con la pena de cien morabatinos de oro, pagaderos al conde de Terranova y su esposa Margarita de Lauria, señores de la villa. Ante situación tan grave los condes tuvieron que intervenir contra bandos e baralles, haciendo responsable al justicia si no encarcelaba a todos los que fueran armados y les rompiera dichas armas ${ }^{69}$.

La guerra de los "dos Pedros" hizo que cesaran los bandos, que volvieron a reaparecer con la paz, como vemos en una carta del 31 de marzo de 1386 de la reina María, tutora del infante Martín, señor de la villa, en la que notificaba al procurador suyo en Alcoi que había ordenado dar un pregón con el fin de evitar los bandos en la villa, pero luego, a través de su Consejo, se enteró que tal medida iba contra fuero y dado que su intención no era ir contra los privilegios de la villa, pidió a su procurador que regresara a la situación anterior, utilizando en el futuro sólo los fueros y privilegios. En el citado pregón se prohibía a cualquier persona organizar peleas o batallas en la villa de Alcoi y su término, bajo la pérdida de la cabeza el hombre de paraje y de ser colgado el hombre honrado o de otra condición, además de la

\footnotetext{
${ }^{67} \mathrm{M}^{\mathrm{a}} \mathrm{T}$. FERRER I MALLOL, Organització i defensa d'un territori fronterer, p. 131.

${ }^{68}$ ARV, Real, 287, f. 83 v. 30-12-1461, Calatayud.

${ }^{69}$ R. SANCHIS LloRÉNS, Cosas de mi pueblo, Alcoy, Caja de Ahorros de Alicante y Murcia, 1982 , p. 40. Anotó el justicia que "era fama pública que per la vila de Alcoy que alcuns hòmens anaven armats de dia e de nit, co és: En Ponç Sisternes e son fill e sos amichs, de una parte, e En Pere Correger, e En Simó Guardiola e sos germans e sos parents, de l'altra, per la qual cosa podrà esdevenir en la vila morts e nafres...
} 
pena de mil morabatinos ${ }^{70}$. Un castigo extremo que refleja la tensión social por la que entonces atravesaba esta localidad, sin que podamos precisar más.

En la mayoría de las localidades de tamaño medio del reino, las casiciudades, encontramos luchas de bandos en uno u otro momento de su etapa medieval, siendo particularmente conflictivos los años de tránsito del siglo XIV al XV. En Cocentaina, dinámica villa en el camino real de Xàtiva a Alicante, y coincidiendo cronológicamente con el resto del reino, había violentas parcialidades a finales del siglo XIV, tal como se aprecia en la carta enviada el 2 de enero de 1397 al justicia de la villa para que apresara y le remitiera a los vecinos culpables de matar a otro morador de la localidad, lo que provocó que, como venganza de sangre, todos los habitantes de la villa se lanzaran a la sedición.

No se calmaron los ánimos y el 21 de agosto de 1399 la reina Violante encargaba a Pere Esplugues que aplacara las tensiones y parcialidades existentes en la villa, de las que podrían seguirse violencia. En este caso sabemos la causa, que no era otra sino los pleitos suscitados por algunas gentes de la localidad contra aquellos vecinos que habían desempeñado funciones públicas en el Consell local ${ }^{71}$.

En efecto, aquí radicaba la causa de los enfrentamientos: el gobierno municipal, cuya crisis era un coletazo más de las dificultades por las que había atravesado el reino en la segunda mitad del siglo XIV. La documentación no lo dice explícitamente, pero un documento del 21 de mayo de 1394 expedido en Valencia por la reina doña Violante, señora de la villa, y dirigido a los jurados y prohombres de la villa puede darnos la clave. En él se dice que desde hacía un tiempo algunos habitantes de melioribus se fueron a vivir a otras localidades por causa de la esterilidad y por otros inconvenientes que se producían, de forma que era imposible encontrar doce personas aptas para ejercer los oficios municipales, lo que ha llevado a que personas inabiles $e$ insuficientes gobiernen la villa. Ello había conducido a una grave situación, por lo que la reina autorizaba a que en dichas elecciones pudieran participar también los clérigos contestanos ${ }^{72}$.

El 20 de enero de 1400 la reina comisionaba a Vidal de Blanes, caballero y su procurador en el reino de Valencia desde 1399, para que solucionara tales discordias, algo que no se consiguió, sino todo lo contrario, pues algunos vecinos atacaron a Blas Martínez, presbítero contestano, al que causaron heridas letales y conspiraban para matar al baile de la villa, Pere Martínez de Vera, al que en adelante veremos como eje de estas luchas de bandos. Doña Violante comisionó el 27 de octubre a Francesc Blanch, doctor

\footnotetext{
${ }^{70}$ ACA, C, reg. 2.107, ff. 46 v-47 r. 31-3-1386, Paterna.

${ }^{71}$ ACA, C, reg. 2031, f. 136 r-v. 21-8-1399, Zaragoza.

${ }^{72}$ ACA, C, reg. 2042, f. 6 v.
} 
en leyes, para que averiguara quiénes eran los culpables y, personalmente o con ayuda de sus oficiales, los apresara y les incoara proceso ${ }^{73}$.

Estas violencias urbanas en Cocentaina eran calificadas como bandositats, como guerras privadas, y gracias a los capítulos remitidos por la reina Violante a Jaume Corner, doctor en leyes, para que castigara a los culpables de estos bandos, conocemos las causas de tales agravios, en los que jugó un papel clave Pere Martínez de Vera, el baile de la villa, y sus partidarios partida dels jurats de la vila damunt dita, qui són adjunts ab lo dit batle en grau de parentela o affinitat.

Recordemos que el linaje de los Martínez de Vera era oriundo de Soria, de donde pasaron al reino de Valencia en el siglo XIV, estableciéndose en Cocentaina en 1330. Pere Martínez de Vera casó con Ana Pascual, de Alicante. Tuvieron por hijos a Joan, Pascual, Isabel y Pere. Testó en Cocentaina el 10-4-1394. Nuestro personaje era hijo de Pere Martínez de Vera y Ana Pascual, y hermano de Joan Martínez de Vera. Era caballero y en 1400 desempeñaba las funciones de alcaide y baile de Cocentaina, oficios en los que sucedió a Miquel de Novals. Se mantuvo en el cargo hasta el 2 de julio de 1422 en que fue sustituido por Miquel Rotlà. El cronista L. Fullana se hizo eco en su Historia de Cocentaina de los desmanes y abuso de autoridad de Pere Martínez de Vera, recogiendo las protestas contra dicho funcionario por parte de la villa, aunque sin entrar a analizarlas. Su juicio sobre el mencionado personaje se resume en estas palabras: "Había logrado Martínez de Vera dominar por completo en la villa de Cocentaina, tanto por sus cualidades de verdadero político como por el ascendiente de toda su familia"74.

El memorial le fue remitido a la señora de la villa y en él se acusaba a Martínez de Vera de perpetrar alguns malifficis, por los que era merecedor de ser punido en grans penes corporals e peccuniaries, al haber ido contra la cosa pública de la villa y la destrucción de su población. En primer lugar, el baile promovió cierto día una pelea en la corte del justicia mientras este oficial juzgaba. Se trataba de una trasgresión sin precedentes la invasión con violencia de un tribunal municipal, ya que el baile sacó la espada y atacó a Miquel Muntoro y Martín Domínguez -arriba encausados- $e$ desonràvals de bocha e de mans, estando presente el justicia, lo que resultaba intolerable para el oficio de la bailía.

Por su parte, Diego Martínez, yerno de Pere Martínez de Vera, por instigación de éste, salió un día al camino real armado sobre un caballo con intención de matar a Rodrigo Domínguez lo qual era ab lo dit Diago Martínez en sagrament e homenatge y ambos tenían paz, bajo cierta penas pecuniarias. Todo apunta a que los Martínez de Vera y los Domínguez, junto con los

\footnotetext{
${ }^{73}$ ACA, C, reg. 2047, ff. 11 v-12 r. 27-10-1400, Barcelona. Francesc Blanch debía remitir el proceso a la reina para que ella proveyera en justicia. L. FULLANA MIRA, Historia de la villa y condado de Cocentaina, Valencia, 1920. Reedición por el Monte de Piedad y Caja de Ahorros y condado de Cocentaina, Valencia, 1920. R.
de Alencia, Cosmos, 1975, p. 216.

${ }^{74}$ L. Fullana MiRA, Historia de la villa y condado de Cocentaina, Valencia, 1920 Reedición por el Monte de Piedad y Caja de Ahorros de Alcoy, Valencia, Cosmos, 1975, p. 220.
} 
Muntoro, eran algunos de los bandos implicados. Domínguez iba tranquilamente por el camino de Cocentaina a Valencia sin sospechar que lo esperaban para matarle, y así hubiera sucedido sino que Déu feu soberana gràcia al dit Rodrigo, de modo que gracias a la intervención divina y a que supo defenderse salvó la vida. En eso que llegó Pero Martínez con algunos amigos y parientes qui són en liga e manipoli ab los dits sogre e gendre y propusieron a gritos ir a incendiar la casa de Martín Domínguez, lo que pudo ser evitado por la intervención del justicia y de otros muchos vecinos.

La implicación de los cargos municipales en los bandos era muy clara, pues al día siguiente algunos jurados de Cocentaina parientes de Pere y Diego Martínez recorrieron la villa forzando a algunos a prestarles juramento y homenaje que estarían en su bando (que serian de la lur valença) y forzaban al justicia a que aquellos que no querían aceptarlo fueran arrestados o expulsados del término de la villa com ells los haguessen per enemichs capitals.

En estos episodios alterna la violencia colectiva con la individual, que en ocasiones tiene como víctimas a las mujeres de personajes implicados en el conflicto. Las violaciones por parte de personajes varones del bando contrario no eran infrecuentes, ya que de este modo se deshonraba el linaje afectado. La gravedad de la ofensa traía como consecuencia un empeoramiento y recrudecimiento de la lucha. A veces, incluso se producían desplazamientos de la población En el caso contestano se nos dice que el primo hermano de Pere Martínez, el cabeza del bando, intentó forzar varias veces a la mujer de Antoni Tolrà, quien se quejó a su marido y éste al justicia. La respuesta del bando de los Martínez fue amenazarle de muerte si decía algo, por lo que Antoni Tolrà y tres familias de su parentela (tres casades) tuvieron que abandonar Cocentaina y refugiarse en Oliva, con el consiguiente drama familiar.

Si el caso anterior quedó en intentó de violación, en el siguiente ésta se consumó, al forzar el citado personaje a la esposa de Jaume Robert. Éste pidió al justicia que actuara contra el culpable, pero Pere Martínez de Vera acusó a Jaume de difamador y ordenó al justicia que lo apresara, acabando en la cárcel, hasta que pudo recobrar la libertad y, como en el caso anterior, tuvo que emigrar con toda su familia e instalarse en Villena.

Las tropelías de la familia del baile contestano parecían no tener límite y así sabemos que un sobrino suyo escaló la casa de Galcerà Martí para violar a su mujer, y como Martí no se atreviera a decir nada le dieron dos bofetones y querían matarlo. El instigador de todos estos sucesos era el baile Pere Martínez y su osadía y fanfarronería era tal que justícia ni altre oficial de la dita vila no li gosa res dir.

De nuevo vemos en acción al primo hermano de Pere Martínez, un peligroso violador, pues quiso forzar también a la hija de Domingo Pérez, pero esta fue corriendo a la casa de su padre, donde se refugió. Tan pronto como el baile supo lo sucedido fue corriendo a casa de Domingo Pérez y le pidió que callara el suceso o de lo contrario que's tingués per convidat axí com los altres. O sea, silencio o cárcel o destierro. Ante tal bravuconería, abusos y falta de justicia muchas familias abandonaron Cocentaina y se fueron 
a vivir a otras localidades, hasta el punto de que, si no interviene la reina, la dita vila per desabitada. Una afirmación sin duda extrema para forzar la intervención de la señoría, pero que reflejaba la angustia y el desamparo de una parte de la población.

El poder y la justicia estaban en manos de Martínez de Vera y su familia, pues el justicia de la villa, Guillem Serra, era su cuñado. Contra éste se elevó una queja porque intentó matar con la espada a Martín de Moya, quien pidió ayuda al procurador. La respuesta de Martínez de Vera fue que quant l'aguessen mort, ja per axò no's exiria de la vila, por lo que, ante tal amenaza, Moya emigró con su familia a Oliva.

El baile Martínez de Vera atacó con sus primos la casa de Bernat de Fluvià, capellán de la reina, por motivos nimios, que le serían explicados, razón por la que marchó con su casa a instalarse en Gandía.

Otro motivo de queja contra el baile era la prisión de una musulmana, que estaba en la cárcel y que fue dada por fugitiva. La prisionera, según relató del sayón que la tenía presa, pagó a Pere Martínez de Vera 150 florines, siendo amenazado el sayón si decía algo, por lo que tuvo que emigrar también con su familia a Xàtiva.

A ello se añadían otras muchas composiciones hechas por el citado baile, de las que no daba cuenta a nadie ni las anotaba en sus cuentas, tal como probarían los mensajeros a la reina.

Su nepotismo llegó al extremo de intentar echar a Jaume Capello de la corte de la bailía para darle el cargo a un sobrino suyo, per tal que negun no sapia so que ell fa. Había que eliminar cualquier ojo fiscalizador y dejarlo todo controlado por la familia, tal era el objetivo de Martínez de Vera.

No contento con estos atropellos, incluso metió mano en las propiedades de la señoría, cortando toda la madera del pinar de Penella, que era de la reina, dándola y repartiéndola entre sus parientes, quedándose la reina sin nada y el pinar perdió su valor hasta una suma inferior a los 500 florines.

Otra queja aludía al desprecio de las decisiones de la señoría, ya que Gil Roiç, lugarteniente del procurador, había ordenado al baile y a los jurados de la villa, bajo la pena de 500 morabatines, que no colocaran para la elección de justicia a nadie que formara parte de los bandos, lo que Pere Martínez no respetó, poniendo a su cuñado, que era la cabeza del bando junto con su hijo. Testimonio importante, porque nos da a conocer en quién recaía la jefatura del citado bando: Guillem Serra, que, como vimos, era el justicia local.

El último agravio tuvo lugar el día de San Esteban, prop festes de Nadal, y fue motivado por la noticia llegada a oídos de Martínez de Vera de que algunos enemigos suyos se habían marchado al cercano lugar de Muro, en el término de la villa. Al medio día Pere Martínez envió a su yerno con otros amigos y a mano armada entraron en Muro, rompiendo las puertas de una casa que era de Andreu Amich, de Muro, y con las espadas desenvainadas buscaron por toda la casa a sus enemigos, sin encontrarlos. En el registro le desparramaron por las esteras al dueño de la casa gran cantidad de trigo que tenía guardado en cofines. Como consecuencia del tumulto la mujer de Amich la qual era preys e grossa sufrió un ataque de nervios del miedo que pasó, y 
hasta la fecha no és be catòlica, es decir quedó trastornada. Cuando el afectado quiso reclamar al procurador de la señoría, Pere Martínez amenazó al citado oficial diciéndole que quant anàs a la laurada, que anàs ab les cuyraces en l'esquena, es decir, que fuera bien protegido por lo que pudiera pasarle $^{75}$.

Al día siguiente, el 14 de mayo de 1401 la reina escribía a su procurador en el reino de Valencia, Vidal de Blanes, y al justicia de la villa y les manifestaba su disgusto por tales guerras privadas y por el daño que causaban a la paz pública, por lo que, a fin de que la gente viviera en paz, les ordenaba que obligara a firmar la paz a todos aquellos que quisieran, expulsando de Cocentaina y apelando a los medios que creyeran oportunos contra los que no lo hicieran. La importancia del delito superaba el marco de la justicia local, por lo que en otra carta de ese mismo día ordenaba a Guillem Cordelles, justicia de Cocentaina, bajo la pena de 500 morabatinos, que no se entrometiera en ninguna causa civil o criminal en la que estuvieran Martí Domínguez y sus hijos, Miquel Muntoro y sus hijos, Jaume Doménech, Lluís Casoner, Nicolau y Rodrigo Muntoro, ni en sus mujeres, hijos o bienes, remitiéndolas a su procurador general, Vidal de Blanes, para que las resolviera ${ }^{76}$.

El citado memorial de agravios fue remitido el 14 de mayo por doña Violante a su consejero Jaume Corner, doctor en leyes, para que investigara la verdad de su contenido y procediera contra los culpables, pudiendo arrestarlos y embargarles. Enterada la reina de la mala conducta de Pero Martínez de Vera, baile de la villa, abusando en la elección anual del justicia, jurados, mostaçaf y otros oficiales de la villa en nombre de ella, eligiendo personas ineptas para tales oficios, le pedía que se enterara de lo sucedido y de ser cierto que la próxima elección la hiciera el baile con la ayuda de Forner ${ }^{77}$.

La tensión forzó la intervención de la señora de Cocentaina para que los bandos llegaran a una tregua, que por una carta de la reina Violante del 13 de diciembre de 1401 sabemos que debía durar hasta el 2 de febrero del año 1402 (tro a Sancta Maria de febrer propvinent). El riesgo de que las luchas urbanas prosiguieran pasada esta fecha era muy alto, por lo que la reina pedía a mosén Vidal de Blanes, gobernador general del reino, que façats tot esforç que fer puxats e tingats maneres e enginys, de forma que dichos bandos hicieran la paz ${ }^{78}$.

La violencia se trasladó también a pequeñas localidades, como el lugar -entonces alquería- de Muro, que dependía de Cocentaina. Lo sabemos por

\footnotetext{
${ }^{75}$ ACA, C, reg. 2047, ff. 53 v-55 r. 13-5-1401, Barcelona.

${ }^{76}$ ACA, C, reg. 2047, f. 52 v. 14-5-1401, Barcelona.

${ }^{77}$ ACA, C, reg. 2047, f. 53 r-v. 14-5-1401, Barcelona.

${ }^{78} \mathrm{ACA}$, C. reg. 2.032 , f. 35 v. 13-12-1401, Barcelona. La reina notificaba a Blanes el nombramiento de Bernat Claver como su procurador, que recibiría todas las rentas de la localidad, las suyas y las del rey.
} 
el perdón que el 15 de febrero de 1403 la reina Violante concedió a Guillem Martín, de Muro, hijo de Miquel Martín, que había matado a Pere Cocorilla, de Cocentaina. El perdón alcanzaba también a Matías y Jaume Cocorilla, vengadores de la muerte de su hermano al dar muerte de Guillem Martí, el padre del citado Guillem Martí. Huidos de Cocentaina se habían refugiado en la vecina Albaida. El perdón aparecía como una de las soluciones para aplacar las venganzas familiares, que parecían no tener fin.

A Vidal de Blanes le sucedió en la misión de pacificar los bandos de la villa el noble Lluís Alamán de Cervelló, procurador general de la reina, teniendo como lugarteniente a Galcerà Saera, doncel, y el 10 de marzo de 1403 Alamán de Cervelló fue sustituido por Bernat Sacot, consejero y escribano de porción de doña Violante ${ }^{79}$. En una misiva dirigida el 20 de marzo a Pere Martínez de Vera, baile de la localidad, así como al justicia y otros oficiales les recordaba su obligación de proceder contra los culpables de los desmanes cometidos en la villa, ordenándoles el embargo de sus bienes, ya que estaban acusados de asaltar viviendas y otros delitos. La petición de la reina estaba motivada por la gran pelea que a principios de marzo hubo en la villa.

La denuncia puesta ante el procurador fiscal el 16 de abril de 1403 por Rodrigo Domínguez, a la cabeza de uno de los bandos, contra Pere Martínez de Vera, alcaide y baile de Cocentaina, fue recibida por el notario de Jijona Guillem Vendrell, Andreu de Pujacons y Domingo Pereç, notarios de Cocentaina, que la expusieron en el Consejo de doña Violante, dando a continuación sentencia el 28 de mayo. En ella la reina señalaba que la mayoría de las quejas presentadas contra el baile no eran competencia del citado Rodríguez sino de los interesados afectados por las actuaciones de Martínez de Vera. Por ejemplo, la reina decía que ya tenía quien le impugnara las cuentas que el baile le debía dar, y que lo que se había buscado era calumniar a Martínez de Vera, por lo que en la sentencia declaraba a éste absuelto de tales acusaciones y se condena a Rodrigo Domínguez a pagar las costas per tal com se és anat maliciosament e sens causa alcuna contra lo dit nostre alcayt e batle e que s'es entramés de posar e causar defets d'altri e no seus ${ }^{80}$.

Lo cierto es que, además de los fundamentos de derecho, Pere Martínez de Vera, perteneciente al estamento de la caballería, como doncel que era, controlaba la villa, y contaba con importantes valedores y su destitución hubiera agravado la situación.

En mayo de 1404 de nuevo subió la inquietud generada por los bandos en el reino. El día 14 la reina Violante notificaba a Pere Martínez de Vera, el baile de Cocentaina, que en el valle de Cárcer y en otras zonas vecinas de Cocentaina se estaban reuniendo gentes que podrían ser una amenaza para la villa, por lo que le pedía que no permitiera que los citados bandos o sus

\footnotetext{
${ }^{79}$ ACA, C, reg. 2032, f. 85 r-v. La reina reclamó a Alamán de Cervelló a su servicio en Valencia otorgando a Sacot la jurisdicción civil y criminal en Cocentaina. Ordenaba a las autoridades de la villa que le obedecieran y ayudaran en su lucha contra los disturbios.

${ }^{80} \mathrm{ACA}, \mathrm{C}$, reg. 2047, ff. 168 r-169 v. 
partidarios entraran en Cocentaina. Si quisieran estar en los arrabales para refrescarse debía tener bien cerrados los portales de la villa, avisando a todas las villas y castillos de la baronía para que estuvieran preparados ante cualquier contingencia ${ }^{81}$. Esta prohibición de acoger a gente de los bandos y tener cerrados los portales de la muralla fue reiterada el 11 de enero de 1406.

En 1413 el bando de los Martínez de Vera seguía activo, estando al frente del mismo Joan Martínez de Vera, del que sabemos que quizá el año anterior estaba en Aragón, posiblemente escapando de la acción de la justicia de doña Violante, pues en una carta que ésta dirigía el 14 de enero de 1413 a su procurador general en el reino de Valencia, Vidal de Blanes, le respondía a propósito del proceso de Joan Martínez y cómo éste a su regreso de Aragón manifestó el deseo de acudir personalmente a presencia de la reina, lo que no había hecho, por lo que doña Violante pensaba que se trataba de maniobras dilatorias, como siempre hacía este personaje, y ordenaba que se procediera contra él y sus fiadores ${ }^{82}$.

El enfrentamiento era entre Joan Martínez de Vera y Berenguer Marí, cabezas de los respectivos bandos, y la reina actuando como árbitro dispuso el 2 de febrero de 1413 que se firmara una tregua general de 101 años y la paz perpetua entre las partes, ordenando a su procurador, Vidal de Blanes, que anulara todos los procesos, inventarios y expulsiones dictados por dichos bandos. Se exceptuaba el proceso contra Antoni Daroca y Miquel Morant, que, por razones que no se especifican, quedaban excluidos de dicha paz ${ }^{83}$. Ambos personajes en el plazo de tres días se pondrían a disposición del procurador para ser castigados o absueltos de los delitos de que se les acusaba. Ese mismo día la reina ordenaba a su procurador y a todas las autoridades de Cocentaina que tan pronto como tuvieran noticia de cualquier pelea o bando, impidieran de inmediato su formación, apresando a los culpables y castigándolos de modo ejemplar.

A pesar de tan drásticas órdenes hay noticia de un episodio violento el día de Pascua de 1419 protagonizado por el ya conocido Berenguer Marí, que era cabeza de uno de los bandos y se peleó con el hijo de mosén Llorens Martí, apoyado por su respectivo bando. Esta vez, doña Violante no estaba dispuesta a ver alterada la paz de la villa, y el 23 de abril escribía a los jurados manifestando su descontento por la pelea, a la vez que satisfacción porque Marí estuviera preso, ya que esperaba darle un castigo ejemplar. Pedía que lo tuvieran custodiado por buenas personas, de forma que si lo reclamaba se lo pudieran remitir. Debían proceder a inventariar los bienes de los culpables en la pelea, que debió ser tumultuosa, ya que se habla en plural, abriendo proceso contra cada uno de ellos. También dio orden, para pacificar la villa, que se apresara al hijo de mosén Martí -en previsión de venganzas-

\footnotetext{
${ }^{81}$ ACA, C, reg. 2051, f. 193 r-v. 14-5-1404, Valencia.

${ }^{82}$ ACA, C, reg. 2057, ff. 54 v-55 r. 14-1-1413, Barcelona.

${ }^{83}$ ACA, C, reg. 2057, ff. 81 v-82 r. 2-3-1413, Barcelona.
} 
e inventariaran sus bienes ${ }^{84}$. En otra misiva dirigida a Vidal de Blanes, su procurador, le ordenaba que fuera a Cocentaina y retomara el proceso que había iniciado el justicia y los jurados de la villa, remitiéndoselo cerrado y sellado a fin de poder ver el delito cometido e imponer los correspondientes castigos.

De momento parece que la situación se calmó, pues en abril de 1420 doña Violante mostraba a Guillem de Rocafull, lugarteniente de su procurador general en el reino de Valencia, su satisfacción porque antes de partir la villa de Cocentaina y sus vasallos quedaban en paz y sosiego. Unos días ante el procurador general, Francesc Sarçola, había ordenado que todos los habitantes prestaran juramento y homenaje de no ofender en persona ni en bienes a algunos de la villa, bajo la pena de destierro para el que no quisiera prestarlo. En el futuro ninguno de los desterrados o sus adheridos a los bandos podría entrar en Cocentaina o Planes, bajo la pena de 200 florines para el culpable o quien lo acogiera.

Pero todo era en vano y los bandos contestanos proseguían en los años veinte de la centuria, como se aprecia en la carta dirigida por doña Violante al justicia y jurados de la localidad acusando recibo sobre la paz tratada entre los bandos, mostrando su satisfacción por dicho acuerdo. Respecto a la petición de perdón que solicitaron ambas partes, la reina respondió que, teniendo que antes hubo muchas treguas que se rompieron, antes de concederlo quería estar bien enterada del contenido de la paz y luego decidiría. No sabemos si estos bandos eran continuación de los anteriores o de nueva formación. Lo que sí sabemos era el motivo de su aparición: el control del Consell municipal, tal como se desprendía del privilegio concedido a la villa el 11 de diciembre de 1421 por la reina Violante a sus vecinos, devolviéndoles el privilegio de elegir los oficios concejiles, cuya elección fue suspendida ante la gravedad de las luchas y bandos que se habían desencadenado. Los elegidos debían comparecer ante la reina, su procurador o el baile ${ }^{85}$.

Las banderías prosiguieron durante el resto de la centuria, aunque no nos han dejado tantas noticias, pudiendo rastrearse a través de la firmas de las llamadas paus e treves, firmadas ante el justicia local. Todo apunta a bandos más pequeños, limitados a los parientes y amigos de unas personas o familias concretas, como vemos, por ejemplo, en la paz que firmaron el 11 de mayo de 1493 los hermanos Joan y Bernat Prats, y Miquel Alberola, pelaires, de un lado, y de otro Alfonso d'Alcaraç, maestro albañil, y su cuñado el terciopelero Bertomeu Ordonyo. No sabemos las causas del enfrentamiento, pero sí que la paz alcanzaba a parents, amichs e valedors que tinguen.

Estas banderías se mantuvieron durante la Edad Moderna en las ciudades valencianas debido a la debilidad de los medios de acción de la monarquía, a la calidad de las personas implicadas, que a menudo solían estar en connivencia con los grandes oficiales reales y los encargados de aplicar la

\footnotetext{
${ }^{84}$ ACA, C, reg. 2052, f. 70 r. 23-4-1419, Barcelona.

${ }^{85}$ ACA, C, reg. 2034, ff. 129 v-130 r. 11-12-1421, Barcelona.
} 
justicia, además de disfrutar de jurisdicciones especiales. A la Corona, a su vez, le interesaba mantener estas banderías y enfrentamientos entre la nobleza, que la mantenía hasta cierto punto desgastada y debilitada, a tener enfrente una nobleza fuerte y cohesionada que, en un momento dado, pudiera hacerle frente. La Corona era consciente de esta situación y nunca buscó acabar de forma definitiva con los bandos, a pesar de algunos castigos ejemplares. Los arrestos, destierros, penas económicas y de cárcel, las paces y treguas y un largo etcétera, no eran sino medidas transitorias para apaciguar temporalmente la violencia, que sólo podía solucionarse de manera definitiva a través de la vía judicial.

Fecha de recepción del artículo: mayo 2006.

Fecha de aceptación y versión final: julio 2006. 